\begin{abstract}
UNIVERSIDADE DE SÃO PAULO
FACULDADE DE FILOSOFIA, LETRAS E CIÊNCIAS HUMANAS DEPARTAMENTO DE TEORIA LITERÁRIA E LITERATURA COMPARADA PROGRAMA DE PÓS-GRADUAÇÃO EM TEORIA LITERÁRIA E LITERATURA COMPARADA
\end{abstract}

ANDERSON MASSARU ARAKAKI

A realidade brasileira na obra de Drummond

São Paulo 


\author{
UNIVERSIDADE DE SÃO PAULO \\ FACULDADE DE FILOSOFIA, LETRAS E CIÊNCIAS HUMANAS \\ DEPARTAMENTO DE TEORIA LITERÁRIA E LITERATURA COMPARADA \\ PROGRAMA DE PÓS-GRADUAÇÃO EM TEORIA LITERÁRIA E LITERATURA \\ COMPARADA
}

\title{
A realidade brasileira na obra de \\ Drummond
}

Anderson Massaru Arakaki

Dissertação apresentada ao Programa de PósGraduação em Teoria Literária e Literatura Comparada do Departamento de Teoria Literária e Literatura Comparada da Faculdade de Filosofia, Letras e Ciências Humanas da Universidade de São Paulo, para obtenção do título de Mestre em Letras

Orientador: Profa. Dra. Betina Bischof

São Paulo 


\section{Resumo / Abstract}

Resumo

A ênfase do estudo é ver a representação do período de 30-60 na obra drummondiana; ou seja, a incorporação da realidade brasileira na subjetividade lírica a partir de alguns pontos específicos: certos traços do país-colônia e do país-burguês na construção da figura do gauche; o discurso da ditadura de Vargas; os novos meios de produção e recepção da arte na década de 40; e o desenvolvimentismo de JK.

Palavras-chave: literatura brasileira, lírica, anos 30-60, estrutura da realidade, Drummond.

\section{Abstract}

Our approach of Drummond's work aims to study the way in which the decades of $30-60$ are represented in his poetry; or the way by which the Brazilian reality is incorporated in the subjectivity of the poet starting from some particular elements: some aspects regarding realities of the country that are due to Brazil's colonialist past, and some aspects that are linked to the modern developments of the country, both seen in the building of the gauche's 
portrait; the dictatorial speech of the Vargas era; new production and reception means of art in the decade of 40's; and the effort towards development in the government of JK.

Key-words: Brazilian literature, poetry, 30-60's, the structure of reality, Drummond.

e-mail: andersonakk@gmail.com 
à minha mãe

e ao meu pai 


\section{Agradecimentos}

Do início da pós-graduação ao seu fim, diversas pessoas - de forma direta ou indireta - estiveram presentes na realização do meu estudo sobre Drummond.

É difícil a tarefa de expor brevemente o tanto que sou grato a Betina Bischof: a sua orientação encarna com delicadeza a frase que diz que o professor

é alguém que tenta recriar o assunto na mente do estudante. Sua estratégia é a de antes de mais nada fazer o estudante reconhecer o que potencialmente já sabe, e isso inclui a quebra dos poderes de repressão interna que o impedem de distinguir o que sabe. Eis a razão de ser o professor, e não o estudante, quem faz a maior parte das perguntas [...] Responder a uma pergunta [...] é consolidar o nível mental em que foi formulada. A menos que se deixe algo de reserva, sugerindo a possibilidade de uma pergunta melhor e mais complexa, o avanço mental do estudante se detém ${ }^{1}$.

Do convívio com Paula, Bruna, Esmeralda, Fábio e Maíra (do grupo de estudos) só tenho a louvar as conversas e os incentivos.

Na qualificação, tive a sorte de ter Alcides Villaça e Ana Paula Pacheco como argüidores: as suas críticas repercutiram a fundo na minha perspectiva do poeta.

Ainda fica o elogio a Luiz Mattos e Maria Vancin, que tornam a pós um

\footnotetext{
${ }^{1}$ Northrop Frye, O código dos códigos: a Bíblia e a literatura, Trad. Flávio Aguiar, São Paulo, Boitempo, 2004, p. 14.
} 
espaço onde existe o cuidado e a atenção com os alunos.

Obrigado ao apoio da minha mãe e do meu pai - sem o qual jamais realizaria o itinerário da pós e da vida, e que me deu a ferramenta para vencer os obstáculos.

Não pode estar de fora a estima à minha irmã - advogada das nossas aspirações.

À minha filha - que tem mais juízo do que eu nos casos fáceis e nos difíceis, e que me ensina dia-a-dia um novo valor (mais lírico) da vida - dedico humildemente todo o meu amor. 


\section{Introdução}

O caso de Drummond é intrínseco à influência da análise da sua psicologia sobre a crítica, a ponto de às vezes ter sido um obstáculo para a análise do seu contexto histórico.

Ora, se um artigo como o de Manuel Bandeira (que viu no humor drummondiano um "jogo automático de alavancas de estabilização" entre os traços irônicos e os sentimentais ${ }^{2}$ ) é mais comum, um livro como o de Vagner Camilo (que apontou o "radicalismo ideológico do partido comunista" e a "especialização do trabalho artístico-literário" no pós-guerra como fatores decisivos para explicar a postura clássica do poeta nos anos $50^{3}$ ) é bem mais insólito.

Só que nem o livro e nem o artigo negligenciam, respectivamente, os aspectos internos e externos da obra de Drummond: os textos se caracterizam por sua ênfase, e não por seu descaso.

De sua parte, Manuel Bandeira tentou um esboço (de todo modo discutível) de um juízo psico-social do humor drummondiano ao dizer brevemente que

os mineiros são, mais que os outros nossos patrícios, dotados daquelas qualidades de reflexão tardia, de atitude à parte, de desconfiança das segundas intenções, de pessimismo, elementos

\footnotetext{
2 Manuel Bandeira, "Carlos Drummond de Andrade", Seleta de prosa, Rio de Janeiro, Nova Fronteira, 1997, pp. 75-77.

${ }^{3}$ Vagner Camilo, Drummond: da rosa do povo à rosa das trevas, São Paulo, Ateliê Editorial, 2001, especialmente pp. 49-96.
} 
todos esses geradores de humour [...] Toda vez que com esse feitio mineiro coincidirem uma sensibilidade rara e o dom da poesia, é de esperar um humorista de grande estilo ${ }^{4}$.

Vagner Camilo, por sua vez, tratou de avisar que (ainda que determinante) o contexto histórico no curso do seu livro é relativizado por causa da especificidade da lírica, "que na grande lição de Adorno [...] é antítese social da sociedade, a um só tempo autônoma e fait sociap? ${ }^{5}$.

Seja como for, procurei encontrar o ponto de equilíbrio entre as abordagens durante os ensaios, e notar de que forma a "poesia subjetiva [de Drummond] é verdade objetiva, é poesia da realidade", de acordo com Carpeaux.

Em resumo: o que tentei fazer, ensaio a ensaio, foi ver a obra drummondiana a partir de alguns pontos objetivos que o poeta organiza, e que tratei por um viés historicamente específico (certos traços do período que se estende de 30 a 60); em outros termos, tentei expor que o poeta incorporou na subjetividade a exterioridade do contexto histórico, e o pôs na estrutura mais profunda de sua obra, que é, então, objetiva e subjetiva.

A fim de dialetizar o indivíduo e a sociedade na análise da obra de Drummond é que me esforcei por apontar que o "externo [...] importa, não como causa, nem como significado, mas como elemento que desempenha um certo papel na constituição da obra, tornando-se, portanto, interno"7; para não

\footnotetext{
${ }^{4}$ Manuel Bandeira, Op. cit., p. 76.

${ }^{5}$ Vagner Camilo, Op. cit., p. 21.

${ }^{6}$ Otto Maria Carpeaux, "Fragmento sobre Carlos Drummond de Andrade", Carlos Drummond de Andrade, Org. Sônia Brayner, Rio de Janeiro, Civilização Brasileira, 1978, pp. 147-148.

${ }^{7}$ Antonio Candido, "Crítica e sociologia", Literatura e sociedade, São Paulo, Ouro sobre Azul, 2006, p. 14.
} 
incorrer no erro da

inadequação da leitura, [que] ainda quando se aferra a fatos históricos efetivos, cuja repercussão na esfera das artes e da cultura em geral parece inarredável, pode conduzir a meros equívocos, se se descuida do modo de ser real dessa poesia [de Drummond], que desde o começo trouxe em si mesma o fermento de superação dos problemas que jamais deixou de incorporar, absorvendo nas camadas profundas a experiência histórica, que não se confunde necessariamente com os eventos de fora ${ }^{8}$.

No ensaio que abre a dissertação, a figura do gauche é vista sob a ótica da realidade brasileira nos decênios de 20-30, isto é, da disposição antagônica do dado atrasado e do dado avançado na estrutura da sociedade; o objetivo é fazer notar que a construção da figura do gauche está diretamente vinculada à incorporação de certos traços do período referido - este aparecerá não como matéria exterior, e sim interior ao sujeito poético (por exemplo, no choque dos valores da cidade do interior e da cidade grande, da família mineira e da experiência da modernidade, da pessoa pública e da pessoa privada), já que é através da subjetividade que as aporias do contexto histórico terão a sua representação na obra.

$\mathrm{Na}$ época acima, o ensaio analisa ainda o leitor a que a obra de Drummond se dirige a partir do uso da provocação. De início, a ênfase está no tratamento que o poeta deu ao cenário cultural vigente, no qual o artista - no caso, modernista - era inserido frente a frente com o afeto do leitor pela tradição literária firmada: por causa da influência do cânone, poucos artistas eram capazes de dar um retrato fiel do indivíduo e da sociedade, pois o

\footnotetext{
${ }^{8}$ Davi Arrigucci Jr., Coração partido: um estudo da poesia reflexiva de Drummond, São Paulo, Cosac Naify, 2002, p. 18.
} 
presente histórico era projetado nas antigas formas de pensar e sentir. 0 objetivo é apontar que Drummond criou uma pintura do indivíduo e da sociedade mais condizente com o contexto histórico imediato; e uma afinidade estrutural entre autor e leitor, o que vai tornar viável, creio, a possibilidade de que a sua poesia interior se converta na verdade objetiva do público.

O ensaio a seguir se detém no poema "Morte do leiteiro" ( $A$ rosa do povo, 1945): a ênfase está em ver de que forma o poeta incorpora e reelabora o discurso da ditadura para apontar a falta de sentido em que este se fundamenta. Já a análise de "Oficina irritada" (Claro enigma, 1951) procura mostrar que Drummond fez da violência ao leitor a representação - no plano da recepção - da violência do contexto histórico. Por sua vez, o ensaio que aborda o poema "F" (Lição de coisas, 1962) tenta rever a relação da obra de Drummond com a estética concreta, tendo por pano de fundo o projeto desenvolvimentista de JK. 


\section{A figura do gauche}

Ce voyageur ailé, comme il est gauche et veule!

Baudelaire

Vai, Carlos! ser gauche na vida.

Drummond

Carpeaux deu conta de expor o ponto que é o cerne do poeta da pedra quando anotou que a sua "poesia subjetiva [...] é verdade objetiva, é poesia da realidade"; em outros termos: por causa da sua obra,

recuperamos - após um século de subjetivismo romântico que terminou em brincadeira, decoração, decadência e desespero - o papel objetivo da poesia. A poesia de Carlos Drummond de Andrade, expressão duma alma muito pessoal, é poesia objetiva. Não precisa de elogios subjetivos. Precisa duma interpretação objetiva ${ }^{9}$.

A idéia deve o seu brilho ao fato de ver no teor subjetivo - intrínseco à lírica, aliás - os sinais e os traços objetivos, ou por outra, o indivíduo incorpora o contexto histórico, tornando inoperante a oposição interior e exterior que supostamente seria a base da lírica: sob esse viés, é viável ver um fundamento realista na representação da subjetividade do poeta da pedra. No mais, a

\footnotetext{
${ }^{9}$ Otto Maria Carpeaux, Op. cit., pp. 147-148.
} 
realidade influencia na formação, é um princípio que age na estrutura da sua obra.

De maneira análoga, Antonio Candido uniu o estudo da psique gauche com o estudo do contexto histórico no seu ensaio sobre o poeta - que vou sintetizar nas linhas a seguir. O texto parte da visão da presença constante e numerosa de imagens gauches, de metáforas referentes ao sujeito torcido em Drummond, o que é um indício de que a

torção é um tema, menos no sentido tradicional de assunto do que no sentido específico da moderna psicologia literária: um núcleo emocional a cuja volta se organiza a experiência poética $^{10}$.

No início, o ensaísta se ocupa, então, com a psicologia do sujeito torcido, da figura do gauche; o que é natural, já que o seu objeto de estudo é a lírica (o mais subjetivo gênero literário de que se tem notícia); o seu interesse era encontrar antes de mais nada, creio, a perspectiva individual que está subjacente à construção da obra.

Mas o argumento não se interrompe aí; para o ensaísta, o tema da torção não está anexado só às imagens do sujeito torcido: a própria realidade é torta na ótica do eu lírico - aqui está o dado novo, que insere a perspectiva social na obra de Drummond; neste ponto, o argumento mais importante é o que diz que

talvez fosse excesso de fantasia dizer que as próprias condições de inteligência do mundo - o

\footnotetext{
${ }^{10}$ Antonio Candido, "Inquietudes na poesia de Drummond", Vários escritos, São Paulo, Duas Cidades, 1995, p. 115.
} 
tempo e o espaço - acompanham as deformações do indivíduo, em notações como: "ondas de éter / curvas, curvas", "curva de um jardim", "curva da noite", "adunca pescaria", "curva perigosa dos cinqüenta", "linha curva que se estende". Mas não há dúvida que para o poeta o mundo social é torto de iniqüidade e incompreensão. Seja uma deformação essencial, seja uma deformação circunstancial (o poeta parece oscilar entre as duas possibilidades), o fato é que ela se articula com a deformação do indivíduo, condicionando-a e sendo condicionada por ela ${ }^{11}$.

Sob esse viés, é fácil dizer que o tema da torção traz uma "reciprocidade de perspectivas" que articula o indivíduo e a sociedade no seio da obra de Drummond, pois esta é um "movimento coeso do ser no mundo, não um assunto, mediante o qual um vê o outro"12.

De poder das idéias acima, o crítico insiste que, devido à "reciprocidade de perspectivas", é viável reinterpretar os temas do indivíduo de acordo com os temas da sociedade na obra de Drummond: ou me engano, ou Antonio Candido tinha em vista o fato de que os dois são frutos de um conjunto análogo de aporias - que o tema da torção aponta de forma correta; apesar de os dois serem analisados sob óticas diferentes - que são caracterizadas por causa da diversidade dos julgamentos. Nas linhas abaixo, transcrevo um trecho do ensaio em que o crítico deu conta de reinterpretar um tema do indivíduo em termos sociais:

a sufocação do ser, que vimos sob as formas do emparedamento e da mutilação no plano individual, aparece no plano social como medo -, motivo importante na tomada de consciência do poeta em sua maturidade. O medo paralisa, sepulta os homens no isolamento, impede a

\footnotetext{
${ }^{11}$ Idem, p. 121.

12 Idem, p. 127.
} 
queda das barreiras e conserva o mundo caduco ${ }^{13}$.

Entre outras coisas, o ensaio acima citado me deu uma ferramenta - a saber, a reciprocidade entre o indivíduo e a sociedade - para reinterpretar a lírica e a crítica de Drummond de acordo com uma conjuntura específica: a realidade brasileira nos decênios de 20-30, época de coexistência de certos traços do país-colônia e do país-burguês - para usar os termos de Roberto Schwarz $^{14}$. O objetivo é apontar que a construção da figura do gauche está inteiramente relacionada com a incorporação da estrutura antagônica da sociedade no período referido. Por causa do contexto histórico específico, o objeto de estudo das linhas abaixo é o livro de estréia: Alguma poesia. Daí a ausência de alguns pontos de relevo da obra de Drummond, que só viriam à luz do dia anos mais tarde.

A entrevista de Alcides Villaça à D.O. Leitura tem uma intuição da relação do gauche com o contexto histórico: o crítico notou que Drummond usou 0

álibi de ser um poeta gauche para poder expressar o seu descentramento de indivíduo

\footnotetext{
${ }^{13}$ Idem, p. 123.

${ }^{14}$ Cf. Roberto Schwarz, "A carroça, o bonde e o poeta modernista", Que horas são?, São Paulo, Companhia das Letras, 1987, pp. 11-28.
} 
moderno, a sua mobilidade por vários humores e vários estilos. O "Poema de sete faces" é uma expressão exemplar desse movimento que vai da piada ao sublime, da confissão comovida à blague, do verso solene à conversa de bar. Como processo expressivo, essa inconstância nervosa tornou-se sua marca e dá forma, creio, às inconstâncias fundamentais de nossa época ${ }^{15}$

A análise é precisa: as inconstâncias de personalidade são o signo característico do gauche. De fato, a técnica cubista no "Poema de sete faces" de que é fruto a sua perspectiva fragmentada - é um artifício artístico que tende a pintar com cores fortes o caráter variado dos traços de estilos e de psicologia. Só que é inespecífica em um ponto: as "inconstâncias fundamentais de nossa época" são uma idéia vasta (isto é, são extensivas a toda a modernidade) para assinalar com rigor os aspectos que constituem um período histórico: no caso do gauche, os anos 20-30.

É provável que a inespecificidade da análise decorra do formato conciso da entrevista, que às vezes se torna um obstáculo para respostas mais extensas; ou do fato de Alcides Villaça considerar mais importante a análise da psicologia do gauche: na entrevista, o crítico tratou de avisar que

numa lírica genuína e moderna como a sua os temas por excelência são os movimentos da própria subjetividade, são os limites de um individualismo que não pode abrir mão de sua verdade, ao mesmo tempo em que a sente como uma condenação ${ }^{16}$.

Apesar de o contexto histórico da análise ser inespecífico, o fato é que o

\footnotetext{
${ }^{15}$ Alcides Celso de Oliveira Villaça, "Contradição feroz", D.O. Leitura, São Paulo, Imprensa Oficial, 2002, n. 20, p. 20.

${ }^{16}$ Idem, p. 21.
} 
crítico teve uma intuição da relação, ou por outra, da afinidade estrutural do poeta e da sua época: a apreciação estilística e psicológica - que diz que o sujeito poético anda entre estilos e posturas distintas - tem raízes em um diagnóstico da modernidade, que não traz um eixo ou um ponto de apoio para o indivíduo - de onde a sua perspectiva fragmentada, expressa no "Poema de sete faces".

É um aspecto próprio da obra de Drummond incorporar as aporias do material histórico no material artístico, que se torna, então, o testemunho da experiência da modernidade.

[...] importa, porém, em certa medida e geralmente, buscar a mediação no facto da forma estética ser conteúdo sedimentado.

Adorno

Só um ano após a publicação do já referido Alguma poesia, Mário de Andrade escreveu o mais influente ensaio que tem como objeto de estudo a obra drummondiana; o crítico definiu no texto o juízo que hoje em dia é um pressuposto para ver o caráter próprio da psique gauche (a saber, o jogo que se dá entre o sentimento e o pensamento): 
intimamente Carlos Drummond de Andrade pra melhor achar pelo livro o tímido que ele é. Pra ele se acomodar, carecia que não tivesse nem a sensibilidade nem a inteligência que possui. Então dava um desses tímidos só tímidos, tão comuns na vida, vencidos sem saber o que são, cuja mediocridade absoluta acaba fazendo-os felizes! Mas Carlos Drummond de Andrade, timidíssimo, é ao mesmo tempo, inteligentíssimo e sensibilíssimo. Coisas que se contrariam com ferocidade. E desse combate toda a poesia dele é feita. Poesia sem água corrente, sem desfiar e concatenar de idéias e estados de sensibilidade, apesar de toda construída sob a gestão da inteligência. Dentro de cada poema as estrofes, às vezes os versos, são explosões isoladas. A sensibilidade, o golpe de inteligência, as quedas de timidez se interseccionam aos pinchos $^{17}$.

Do juízo de Mário, a crítica extraiu, por sua vez, a idéia de atitude irônica, que indica "o eu lírico [que] se desdobra - a crítica já identificou a dramatização e as personae como atitude tipicamente drummondiana - e zomba daquele que sofre"18.

Por causa da ênfase do ensaio de Mário na avaliação psicológica, é de se supor que o contexto histórico - como na análise de Alcides Villaça - seja inespecífico. Só que o texto trata (ainda que de forma breve) da estrutura da sociedade, ou de sua influência sobre o poeta de 30 . Nesse ponto, o contexto histórico tem uma consistência mais pronunciada; nas próprias palavras de Mário,

o seqüestro da vida besta é [...] artisticamente valioso. Ele representa a luta entre o poeta, que é um ser de ação pouca, muito empregado público, com família, caipirismo e paz, enfim, "o

\footnotetext{
${ }^{17}$ Mário de Andrade, "A medida psicológica", Org. Sônia Brayner, Op. cit., Rio de Janeiro, Civilização Brasileira, 1978, p. 68.

${ }^{18}$ Ivone Daré Rabello, "Poesia e humor", Drummond revisitado, Org. Reynaldo Damazio, São Paulo, Universidade São Marcos, 2002, p. 112.
} 
bocejo de felicidade", como ele mesmo o descreveu, e as exigências da vida social contemporânea que já vai atingindo o Brasil das capitais, o ser socializado, de ação muita, eficaz pra sociedade, mais público que íntimo, com maior raio de ação que o cumprimento do dever na família e no empreguinho ${ }^{19}$.

O juízo de Mário traz a história para a teoria dos gêneros: o conceito tradicional da lírica - que diz que "o lirismo se restringe ao homem individual e conseqüentemente às situações e objetos particulares" ${ }^{\text {"20 }}$ - é posto em pauta, já que a exigência da sociedade na época por um raio de ação mais abrangente desdobrava o sujeito poético em público e privado.

No mais, a atitude irônica (vista atrás pelo viés da psicologia) pode ser reinterpretada, pois traz para si um fundo social específico: a realidade brasileira no início do século, nos anos 20-30, período de criação de Alguma poesia.

Aqui está um outro pluralismo na obra de Drummond: de início, o do sujeito partido por causa do caráter próprio da psique gauche - sentimento e pensamento; por fim, o do sujeito partido por causa da natureza da estrutura da sociedade que nos decênios de 20-30 exigia maior participação no social do que outrora para que se tornasse possível a modernização que se deu no pais com os avanços da indústria.

Mário repôs, então, a figura do gauche em termos sociais: a realidade brasileira de 20-30 é não apenas uma pintura externa - isto é, a estrutura da

\footnotetext{
${ }^{19}$ Mário de Andrade, Op. cit., p. 71.

${ }^{20}$ Georg Hegel, "A poesia", Curso de estética: o sistema das artes, Trad. Álvaro Ribeiro, São Paulo, Martins Fontes, 1997, p. 512. Para um resumo dos gêneros e para um panorama da sua historicização, cf., respectivamente, Anatol Rosenfeld, O teatro épico, São Paulo, Perspectiva, 2008, especialmente pp. 15-36; Peter Szondi, Teoria do drama moderno, Trad. Luiz Sérgio Rêpa, São Paulo, Cosac Naify, 2001, especialmente pp. 23-28.
} 
sociedade - mas também uma atitude interna - raio de ação.

Foi no seu ensaio sobre a poesia pau-brasil, de Oswald de Andrade, que Roberto Schwarz sintetizou a época acima citada na fórmula certeira que transcrevo nas linhas a seguir:

a nossa realidade sociológica não parava de colocar lado a lado os traços burguês e préburguês em configurações incontáveis, e até hoje não há como sair de casa sem dar com elas $^{21}$

A visão das diferenças de tratamento (posturas artísticas) do poeta da pedra e do poeta pau-brasil a um material histórico parecido apontará, creio, a especificidade drummondiana. Roberto Schwarz tinha em vista no seu texto a idéia de que na obra de Oswald

a sua mátéria-prima se obtém mediante duas operações: a justaposição de elementos próprios ao Brasil-colônia e ao Brasil-burguês, e a elevação do produto desconjuntado por definição à dignidade de alegoria do país ${ }^{22}$.

A alegoria é exterior em Oswald, já que assinala a estrutura da realidade brasileira nos decênios de 20-30: o choque entre o dado atrasado e o dado

\footnotetext{
${ }^{21}$ Roberto Schwarz, Op. cit., p. 13.

${ }^{22}$ Idem, p. 12.
} 
evoluído, que é matéria própria da poesia pau-brasil (cartões postais da conjuntura tupiniquim).

No caso de Drummond, o cenário é análogo, só que o seu tratamento é divergente: o contexto histórico não é externo ao sujeito poético; está inserido na construção da figura do gauche.

A realidade brasileira do país-colônia se dá na obra de Drummond sob a ótica dos valores da tradição, que o poeta tratou de expor em verso e prosa: o grupo social restrito da família mineira; certa pose da aristocracia (ciosa da pessoa privada); as cicatrizes causadas, derivadas da existência na sociedade interiorana, e outras tantas coisas. Por sua vez, o país-burguês é o espaço da experiência da modernidade: da ciência; do avanço; da técnica; do dever cívico da pessoa pública; do progresso da indústria; da maior gama do leque social (isto é, do contrastar e relacionar de grupos sociais); e a lista não tem um final. Vale a pena dizer de novo, o gauche encena o drama do sujeito partido que incorporou a estrutura antagônica da realidade brasileira na sua subjetividade.

O tom dos poetas é uma das outras diferenças no tratamento do contexto histórico: na poesia pau-brasil, o país

adquire uma surpreendente feição otimista, até eufórica: o Brasil pré-burguês, quase virgem de puritanismo e cálculo econômico, assimila de forma sábia e poética as vantagens do progresso, prefigurando a humanidade pós-burguesa, desrecalcada e fraterna ${ }^{23}$.

O projeto estético e político de Oswald tinha a euforia própria de um poeta distanciado do objeto, ou por outra, a inocência pré-cabralina da poesia

\footnotetext{
${ }^{23}$ Idem, p. 13.
} 
pau-brasil é resultado da "distância que permite passar por alto os antagonismos e envolver as partes contrárias numa mesma simpatia"24; esse dado da sua obra indicava a escolha por não ver (ou ver só de viés) certos traços problemáticos do contexto histórico. Daí que

os achados da inocência oswaldiana paguem a sua plenitude com um quê de irrealidade e infantilismo. Mas sendo Oswald um artista grande e esperto providenciava contrapesos à sua decisão de colocar no "presente do universo" - e com sinal energeticamente positivo! - o nosso provincianismo e as nossas relações rurais atrozes: deu a tudo um certo ar de piada. É neste, e levada em conta a situação complexa a que responde, que se encontra a verdade da poesia pau-brasil, um dos momentos altos da literatura brasileira ${ }^{25}$.

Por sua vez, a realidade brasileira é um repertório de aporias para Drummond: é só pensar que a inocência pré-cabralina de "Infância" (espécie de idílio da família mineira) é um desvio do tom da sua poesia ("E eu não sabia que minha história / era mais bonita que a de Robinson Crusoé"). De fato, o tom do poeta é a ironia: cf. o verso de "Cidadezinha qualquer" que acusa a pasmaceira da vida na cidade do interior ("Eta vida besta, meu Deus”). Já a vida na cidade grande é posta em pauta, por exemplo, no poema "A rua diferente":

\author{
Na minha rua estão cortando árvores \\ botando trilhos \\ construindo casas.
}

Minha rua acordou mudada.

\footnotetext{
24 Idem, p. 21.

25 Idem, pp. 27.28 .
} 
Os vizinhos não se conformam.

Eles não sabem que a vida

tem dessas exigências brutas.

Só minha filha goza o espetáculo

e se diverte com os andaimes,

a luz da solda autógena

e o cimento escorrendo nas formas.

As vantagens do progresso, então, são portadoras de "exigências brutas". O canteiro de obras surge do material de construção (como a solda, o cimento, os andaimes) e da própria construção da estrofe 1: o gerúndio dos verbos imita o ritmo prolongado das etapas do trabalho, pois o curso da obra é inexorável; breve como um sopro de vento, as árvores são o vestígio derradeiro do que foi, agora que as casas e os trilhos dominam a paisagem. De resto, é incerto o sujeito do verbo "estão", o que dá a impressão de que o trabalho é quase impessoal - certamente mecanizado em alguma medida. É como se o progresso tivesse um curso próprio, mais além da vontade do cidadão: seja este consciente da conjuntura da realidade brasileira na época - como o poeta, que a indica de vários ângulos; ou inconsciente dessa conjuntura - é o caso dos vizinhos, que "não sabem" e "não se conformam". No mais, a inocência pré-cabralina é que dá à filha a possibilidade de gozar com o canteiro de obras.

O "certo ar de piada" está, pois, excluído da poesia do poeta da pedra: o seu fundamento é o drama, a consciência das aporias que censura o riso ingênuo - ainda que o poeta tenha praticado o verso em forma de piada na obra de 30, que não tem valor igual aos dos instantâneos pau-brasil. Mário de 


\section{Andrade apontou:}

onde a inteligência prejudicou o poeta e o deformou enormemente, foi em fazer ele aderir aos poemas curtos feitos pra gente dar risada, o poema cocteil, o "poema piada", na expressão feliz de Sérgio Milliet. O poema piada é um dos maiores defeitos a que levaram a poesia brasileira contemporânea. Antes de mais nada, isso é facílimo: há centenas de criadores de anedotas por aí tudo [...] Não é mais humor. Não é ainda sátira. Não creio que esses poemas possam adiantar qualquer coisa ao poeta. E por eles será aplaudido nas rodas dos semiliterarizados das academias e cafés. O que positivamente é uma desgraça ${ }^{26}$.

Teria mais a dizer das diferenças - que são numerosas - entre os poetas, mas os elementos apontados já são suficientes para indicar a especificidade drummondiana.

Por fim, transcrevo um trecho do ensaio de Roberto Schwarz sobre Chico Alvim que resume a postura poética do poeta da pedra e do poeta paubrasil:

até onde sei, Francisco Alvim é o poeta de minha geração que mais profundamente assimilou a lição dos modernistas. A mudança de horizonte entretanto é completa. Basta pensar no deslumbramento com que estes descobriram, assumiram e quiseram transformar em saída histórica as nossas peculiaridades sociais e culturais, "tão Brasil". Em "Elefante" elas existem, estão sistematizadas, têm uns poucos e finos momentos de encantamento lúdico, mas no essencial formam a pesada herança político-moral. Como diz o próprio Chico, trata-se de Oswald revisto à luz de Drummond, ou do encontro com o problema que estava escondido no pitoresco ${ }^{27}$.

\footnotetext{
${ }^{26}$ Mário de Andrade, Op. cit., pp. 69-70.

${ }^{27}$ Roberto Schwarz, "O país do elefante", Caderno Mais!, São Paulo, Folha de São Paulo, 1003-2002.
} 
Meu pára-choque com seu pára-choque.

Chico Buarque / João Bosco

A experiência do choque na modernidade é crítica e crucial: no caso de Drummond, a incorporação do antagonismo da realidade brasileira, que tem a sua representação na figura do gauche. De fato, é sob o signo de "choque social" que o poeta reuniu na sua antologia os versos que tratam do choque do indivíduo com a sociedade ${ }^{28}$.

Davi Arigucci, por sua vez, disse que "o poeta que surgiu em 1930 e acabou se tornando a figura emblemática da poesia moderna no Brasil construiu uma grande obra em que tudo acontece por conflito"29.

A fim de ver a experiência do choque na obra de Drummond, é interessante acompanhar os seus anos de formação: a década de 20, para ser mais preciso. José Maria Cançado disse na biografia do poeta que o jovem

${ }^{28}$ Carlos Drummond de Andrade, Antologia poética, Rio de Janeiro, Record, 1997, p. 5: "ao organizar este volume, o autor [...] cuidou [...] de localizar, na obra publicada, certas características, preocupações e tendências que a condicionam ou definem, em conjunto. $A$ Antologia the pareceu assim mais vertebrada e, por outro lado, espelho mais fiel. / Escolhidos e agrupados os poemas sob esse critério, resultou uma Antologia que não segue a divisão por livros nem obedece a cronologia rigorosa. O texto foi distribuído em nove seções, cada uma contendo material extraído de diferentes obras, e disposto segundo uma ordem interna. O leitor encontrará assim, como pontos de partida ou matéria de poesia: 1) O indivíduo; 2) A terra natal; 3) A família; 4) Amigos; 5) O choque social; 6) O conhecimento amoroso; 7) A própria poesia; 8) Exercícios lúdicos; 9) Uma visão, ou tentativa de, da existência. / Algumas poesias caberiam talvez em outra seção que não a escolhida, ou em mais de uma. A razão da escolha escolha está na tônica da composição, ou no engano do autor. De qualquer modo, é uma arrumação, ou pretende ser".

${ }^{29}$ Davi Arrigucci Jr., Op. cit., p. 15. 
Drummond foi influenciado por Álvaro Moreyra: no período, um escritor de prestígio na literatura brasileira; para o biógrafo,

é um dos mistérios mais complicados da evolução e do estilo de Drummond a maneira fácil e sem nenhuma resistência com que se deixava devorar quase que por fagocitose pelo estilo mole, cético e brando de Álvaro Moreyra ${ }^{30}$.

E linhas abaixo, o biógrafo recorre a John Gledson para achar a chave do mistério, que

tenta explicar "essa aderência juvenil" de Drummond a "uma estética que hoje parece antiquada e um tanto absurda". Sua hipótese é amarga: "Não havia, como diz o próprio Drummond, outro padrão a seguir para o jovem escritor na sua posição que não o restringisse da mesma maneira ou ainda mais". E conclui: "A sua admiração por Moreyra é testemunho da própria penúria da vida literária brasileira em 1920”31.

Drummond publicou no Diário de Minas no ano de 22, sob o pseudônimo de Manoel Fernandes, o poema "Sê como as torres longas e finas", que traz a influência de Álvaro Moreyra:

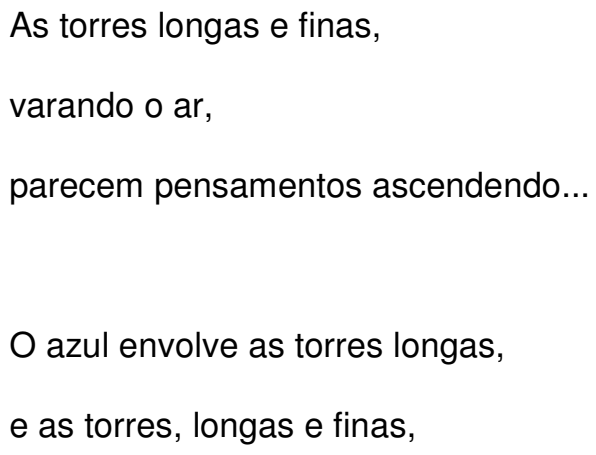

30 José Maria Cançado, Os sapatos de Orfeu, São Paulo, Scritta Editorial, 1993, p. 95.

${ }^{31}$ Idem, pp. 95-96. 
parecem árvores subindo.

As torres querem meditar...

\author{
Lá-baixo, a girar e regirar \\ a vida tumultuosa e inútil \\ a vida vertiginosa e anônima \\ cobre-se toda de poeira...
}

As torres finas

ferem o céu, longas e indiferentes.

O poema não é "essas coisas": no capítulo que trata da obra de 20, John Gledson apontou que o poema tem certos traços modernos: por exemplo, o uso do verso livre e a falta da rima; só que a linguagem permanece tradicional e o estado emocional é tratado de maneira abstrata e simbólica. Drummond concebeu um poema simbolista que se disfarçava de moderno, de acordo com o ensaísta ${ }^{32}$.

Para o poeta de então, a experiência da modernidade era um aspecto abstrato, não se incorporou à sua subjetividade: foi um encontro eventual, e não um conhecer profundo, apesar de sua estadia na cidade grande (RJ em 18, e $\mathrm{BH}$ em 16 e 20). Daí que o poema seja moderno apenas em atitudes técnicas, que não trazem uma postura poética condizente com o contexto histórico, e refletida na estrutura da obra.

No círculo da influência, o ano de 24 foi o decisivo: a excursão da

\footnotetext{
${ }^{32}$ John Gledson. "Os primeiros escritos de Drummond e o modernismo", Poesia e poética em Carlos Drummond de Andrade, São Paulo, Duas Cidades, 1981, pp. 23-56.
} 
caravana paulista por terreno mineiro; o fato é que o poeta achou Mário: foi a descoberta da experiência da modernidade. Drummond recordaria anos mais tarde

que depois do jantar saímos a pé pela avenida Afonso Pena, e que, então realmente descobrimos Mário de Andrade. Já não lembro de que falamos, mas devemos ter falado de tudo, e as respostas de Mário às nossas inquietações eram ruas que se abriam, perspectivas novas, idéias novas, tudo novo. Uma coisa era a idéia literária no papel, funcionando como abstração; outra coisa é o contato humano, a idéia que move os braços, dá uma pirueta, ri e adquire todos os prestígios da voz $z^{33}$.

A fim de ver tal influência, é só pensar que o poeta reuniu as cartas de Mário no livro que tem o sugestivo título de $A$ lição do amigo; ou que a dedicatória de Alguma poesia (obra com uma postura poética verdadeiramente condizente com a experiência da modernidade) é: "A Mário de Andrade, meu amigo"; ou que o poema "Mário de Andrade desce aos infernos", para lumna Maria Simon, "define e aplaude o projeto artístico e humano de Mário de Andrade: a pesquisa cerrada da cultura popular, a penetração concreta na vida, na arte, na linguagem do povo brasileiro"34.

O fato é que o poeta achou na obra de Mário a postura poética para achar a realidade brasileira; o que não teria efeito se não a tivesse tornado atitude própria, isto é, se não tivesse tornado a experiência da modernidade em conhecer profundo - caso contrário, a sua obra traduziria um conhecer sobre, e não um conhecer do objeto de estudo.

\footnotetext{
${ }^{33}$ Carlos Drummond de Andrade apud José Maria Cançado, Op. cit., p. 101.

${ }^{34}$ lumna Maria Simon, A rosa do povo: uma poética do risco, Assis, Faculdade de Filosofia, Ciências e Letras de Assis, 1973, p. 117.
} 
Walter Benjamin definiu os termos do choque na experiência da modernidade no seu ensaio sobre Baudelaire: o poeta francês incorporou os estímulos do século 20 à sua consciência, como matéria própria da interioridade.

O objetivo do procedimento é se proteger do trauma que toca o indivíduo moderno, já que "quanto mais corrente se tornar o registro desses choques no consciente, tanto menos se deverá esperar deles um efeito traumático". Baudelaire, então, "inseriu a experiência do choque no âmago do seu trabalho artístico [...] Abraçou como sua causa aparar os choque, de onde quer que proviessem, com o seu ser espiritual e físico”35.

Daí que o choque com a cidade grande se dê na obra de Baudelaire como uma forma expressiva, ao invés de descritiva, ou por outra, como uma atitude interior, e não exterior:

a massa lhe é tão pouco exterior que nos permite seguir de perto, em sua obra, o modo como ele resiste ao seu envolvimento e à sua atração. Em Baudelaire, a massa é de tão modo intrínseca que em vão buscamos nele a sua descrição. Assim, seus mais importantes temas quase nunca são encontrados sob a forma descritiva. Como Desjardins declara com argúcia a ele "interessa mais imprimir a imagem na memória do que enfeitá-la e cobri-la". Em vão, procurar-se-á, tanto em As flores do mal, como em O spleen de Paris, um tema equivalente aos afrescos em que Victor Hugo era mestre. Baudelaire não descreve nem a população, nem a cidade. Ao abrir mão de tais descrições colocou-se em condições de evocar uma na imagem da outra. Sua multidão é sempre a da cidade grande; a sua Paris é invariavelmente superpovoada. Isto é o que o faz bem superior a Barbier, para quem as massas e a cidade se

${ }^{35}$ Walter Benjamin, Charles Baudelaire: um lírico no auge do capitalismo, Trad. José Martins Barbosa / Hemerson Alves Baptista, São Paulo, Brasiliense, 1989, respectivamente pp. 109 e 111. 
dissociam, por ser o seu um método descritivo ${ }^{36}$

No instante que o contexto histórico do país-colônia e do país-burguês se torna parte do sujeito poético, é fácil dizer que o poeta da pedra traz um conjunto de citações cruzadas para a sua obra, já que incorporou não só um dos (ou os dois) países, mas a própria disposição antagônica da estrutura da realidade brasileira.

Benjamin comentou que Baudelaire trazia a figura da multidão na figura da cidade grande por ser a sua obra a pintura interior, e não exterior da experiência da modernidade; por sua raiz brasileira, o poeta da pedra trazia a figura do país-colônia na figura do país-burguês, o que abre espaço, para Betina Bischof, a um

modo contrastivo de pensar a realidade que, ao menos para o autor de $A$ rosa do povo, parece iluminar tanto um quanto outro pólo de uma trama que engloba uma geografia (Minas / metrópole), um mapa afetivo, diferentes modos de produção, diferentes impasses e aporias $^{37}$.

O choque no gauche faz parte do indivíduo (sujeito partido), da sociedade (disposição antagônica) e duelo entre os dois. Drummond incorporou a realidade brasileira para se proteger do trauma que toca o brasileiro. E criou o modelo tropical do gauche, que não é o "prince des nuées" (que absorve o choque e ostenta o domínio do sujeito poético), mas o "pobre diabo", que absorve o choque e cria a afinidade estrutural do indivíduo e

\footnotetext{
${ }^{36}$ Idem, pp. 115.116.

${ }^{37}$ Betina Bischof, Razão da recusa: um estudo da poesia de Carlos Drummond de Andrade, São Paulo, Nankin, 2005, p. 29.
} 
da sociedade para ter ciência da fragilidade da sua arquitetura: síntese capenga que traz o projeto estético e político de não recalcar as aporias do contexto histórico na sua obra.

A singularidade psíquica e social do poeta se acentua quando reparamos em sua origem social. Todos os poetas modernos, salvo meia dúzia de aristocratas, têm pertencido à classe média. Todos tiveram uma educação universitária; uns saíram advogados e jornalistas, outros médicos, professores, diplomatas, publicitários, banqueiros, negociantes, pequenos ou grandes burocratas [...] Em resumo, todos foram produtos da grande criação histórica da modernidade: a burguesia. E por isso mesmo todos foram, sem exceção, inimigos violentos da modernidade. Inimigos e vítimas. Assim, novo paradoxo, foram plenamente modernos.

Octavio Paz

A frase da epígrafe se torna mais clara ao se notar que para Octavio Paz a experiência da modernidade é a negação do instante que passou, e a afirmação do porvir, que já está destinado a se autonegar: é um transcurso 
autofágico com um quê de dialético, já que o traço característico da era moderna é ser a era da razão. É fácil dizer que o ensaísta tinha em vista Baudelaire: o poeta que criou a partir de Edgar Allan Poe a tradição da lírica crítica.

No caso de Drummond, o movimento dialético da sua obra se faz da disposição antagônica da realidade brasileira: certos traços do país-colônia e do país-burguês.

Merquior disse certa vez que o contraste com a cidade do interior dá ao poeta um ponto para criticar a cidade grande, uma vez que

a ambivalência dos sentimentos de Drummond no que refere ao núcleo familiar e também aos antepassados parece no fundo confirmar sua posição de homem que cavalga dois mundos sociais, dois universos de cultura: o Brasil tradicional da fazenda e o Brasil moderno, urbanizado. [Drummond] conservará sempre o estofo de um liberal de esquerda. Nada há, pois, de cego ou de ingênuo na sua maneira de considerar o ser social da família patriarcal: ele se dá conta, perfeitamente, de seus aspectos repressivos, até mesmo tirânicos. Contudo, em Drummond, a visão social se liga a uma autêntica crítica da cultura; à crítica da burguesia (incluindo a burguesia senhorial das fazendas), se junta uma análise não menos desencantada do estilo de vida da sociedade moderna, "burguesa" ou não. [...] Sem de forma alguma abandonar sua lucidez no tocante ao patriarcalismo, Drummond, pelo contraste que estabelece entre o estilo existencial da sociedade patriarcal e o das massas urbanas alienadas, se reconcilia dialeticamente com o grupo familiar de feição tradicional, seguramente menos frio e inumano que o espaço reificado da grande cidade. É então que a perda de Itabira se torna dolorosa, ainda que o poeta, testemunha perfeitamente consciente de uma época de transição, e sem jamais identificar-se, a rigor, com qualquer forma social, não chegue a pregar a restauração de qualquer passado ${ }^{38}$.

38 José Guilherme Merquior, Verso universo em Drummond, Rio de Janeiro, José Olympio, 1976, pp. 93-94 apud Betina Bischof, Op. cit., pp. 88-89. 
No poema "Explicação", os versos "no elevador penso na roça, / na roça penso no elevador" são uma síntese perfeita da frase acima: a postura indecisa do poeta traz o movimento dialético na obra de Drummond, que relativiza certos traços do país-colônia e do país-burguês. Só que Merquior deu estima demais, creio, ao nexo da crítica da cultura com o pensamento de esquerda, 0 que o impediu de ver as implicações que a idéia do choque entre estilos sociais carrega.

É evidente que Drummond teve relação com a esquerda - $A$ rosa do povo é o caso da adesão incisiva aos princípios do socialismo; mas estou inferindo a hipótese de que a crítica da cultura decorra antes do modo próprio de o poeta incorporar a realidade brasileira.

Vagner Camilo deu um juízo sugestivo da dialética na obra de Drummond a partir da visão da crônica "Poesia e trabalhador"39: o analista articula a classe média com o pobre diabo, com os intelectuais, e aí indica (de acordo com o estudo de Paulo Arantes) a raiz histórica da dialética; por ora, é

\footnotetext{
${ }^{39}$ Nas linhas a seguir, transcrevo a parte do texto que o crítico indica: "na luta entre o possuidor e o despossuído, que marca o nosso tempo, torna-se curioso observar que nem sempre é este que mais sofre às mãos daquele: é muitas vezes o que está no meio, acusado por uns de se vender ao ouro dos plutocratas, por outros de se deixar intimidar ante a cólera dos proletários. Inculpam-no de vacilação, timidez, frustração e não sei que outros pecados, mas se esta vacilação reflete antes um escrúpulo moral, um estado de consciência vigilante, que não aceita deixar-se vencer pela paixão dos outros nem sequer pela sua própria - como recriminá-la? Louvada seja, ao contrário, porque não se confunde com a decisão imediata e irracional nem com a resolução fria dos que agem contra os seus pendores mais profundos, mas de acordo com uma ordem exterior. De resto, costuma-se denunciar a vacilação em nome da firmeza política, e este é afinal um ledo engano, se considerarmos que ainda estão por nascer homens mais vacilantes, mais hesitantes, mais contraditórios do que os chamados líderes políticos dos povos, nesta época e em todas as épocas. Assim, não é vacilação em si aquilo de que se acusa o pequeno burguês recalcitrante; mas a vacilação em obedecer a um 'mandamento' transmitido por vontades vacilantes, ondulantes, incoerentes".
} 
suficiente dizer que a classe média é o espaço do pobre diabo, um

patético pequeno-burguês quase sempre alistado nas hostes do funcionalismo público mais mal pago [...] À beira do naufrágio econômico que ameaça atirá-lo a todo instante à porta da fábrica ou ao desamparo da sarjeta, onde terá de abandonar os restos do seu orgulho de classe $^{40}$.

Não é difícil apontar que a figura do gauche tem certos traços do pobre diabo. O poeta disse em "Confidência do itabirano":

\author{
Tive ouro, tive gado, tive fazendas. \\ Hoje sou funcionário público. \\ Itabira é apenas uma fotografia na parede. \\ Mas como dói!
}

A crônica é importante para Vagner Camilo porque aponta a posição de Drummond ante o teor ideológico do partido comunista, que exigia o realismo socialista na arte, por exemplo, o que indica que,

lida à luz do contexto traçado aqui, a vacilação consciente e deliberada da classe média surge como estratégia de combate ao dogmatismo impondo o alinhamento explícito e a vigilância interna [...] Contra essa firmeza política enganosa, que era a do próprio partido, a oscilação pequeno-burguesa, consciente e abertamente assumida, tem o mérito de permitir flagrar a realidade por vários ângulos sem se deixar "vencer pela paixão dos outros nem sequer pela sua própria”41.

\footnotetext{
${ }^{40}$ José Paulo Paes, "O pobre diabo no romance brasileiro", Novos estudos Cebrap, São Paulo, 1988, n. 20, p. 40 apud Vagner Camilo, Op. cit., p. 81.

${ }^{41}$ Vagner Camilo, Op. cit., p. 79.
} 
Mas o analista trata de dizer que o grau de consciência que a crônica propõe é acentuado a ponto de se poder argumentar que o poeta "advoga aqui em causa própria, pois seria difícil estender a toda uma classe social tamanho grau de 'consciência vigilante' por trás de uma atitude deliberadamente oscilante" ${ }^{42}$.

A idéia que vem após é que a crônica abordaria não a classe média, mas os intelectuais, pois

é possível pensar que Drummond tinha em mente não uma classe historicamente constituída, como a brasileira, mas um conceito mais abstrato de classe média. Ou ainda que visava não o conjunto da classe média, mas uma parcela freqüentemente associada a ela: a dos intelectuais, cuja natureza cambiante e contraditória guarda uma afinidade secular com a classe em questão ${ }^{43}$.

$\mathrm{Na}$ hora que articula a classe média com os intelectuais, o analista abre terreno para trazer as idéias de Paulo Arantes para o seu ensaio, o qual aponta que

essa afinidade secular [...] chega a ser mesmo estrutural, unindo o intelectual e o pequenoburguês [...] A natureza essencialmente contraditória da pequena burguesia laminada pelas duas classes fundamentais, sendo ofuscada pela grande burguesia e compadecida dos sofrimentos dos povos; essa mesma natureza que levou Marx a defini-la como "a própria contradição social em ação" é assim extensiva a intelectualidade ${ }^{44}$.

Por essa ótica, da afinidade estrutural da classe média com os

\footnotetext{
42 Idem, p. 80.

43 Idem, p. 82.

44 Idem, p. 83.
} 
intelectuais decorre "uma certa predisposição para a dialética". O objetivo de Paulo Arantes é, então, achar uma raiz histórica para a dialética na modernidade, é

justificar o renascimento moderno da dialética (ou melhor, das dialéticas, já que ele considera várias formas dialetizantes, como a conversão 'brilhante' da vida mundana, a ironia, o niilismo, o paradoxo, etc.) em bases sociais mais precisas. Longe de ser vista como um aparato lógico atemporal, a dialética formaliza, através de seu 'sistema de báscula', como diria Hegel, uma experiência ou conduta (oscilante) de classe historicamente dirigida ${ }^{45}$.

Vagner Camilo vê aqui o apoio histórico para a interpretação de Claro enigma - obra que já foi vista como avessa aos eventos ${ }^{46}$ : o emprego recorrente dos oxímoros na obra de 51 seria a representação da atitude oscilante da classe média e dos intelectuais (com ênfase na luta ao teor ideológico do partido comunista).

Já que o meu objeto de estudo não é Claro enigma, é hora de ver de perto o movimento dialético de Drummond no período de 20-30 a partir das idéias acima.

A postura indecisa está na figura do gauche, que traiu a sua classe de origem, da qual, entretanto, nunca tratou de se desvincular inteiramente. $\mathrm{Na}$ qualificação, Ana Paula Pacheco me sugeriu que o verso "Vai, Carlos! ser

\footnotetext{
${ }^{45}$ Idem, p. 84.

${ }^{46}$ Cf. Haroldo de Campos, "Drummond, mestre de coisas", Org. Sônia Brayner, Op. cit., p. 248: "Les évéments m'ennuient", Valéry, é a significativa epígrafe de Claro enigma. E ei-lo a praticar esse tédio alienante, reescrevendo em soneto ("Legado") o seu "No meio do caminho tinha uma pedra", que virou "uma pedra que havia em meio do caminho", em polida e castiça chavede-ouro. Isto para demonstrar, talvez - como se fosse possível prestar tributo à tradição viva senão pela criação viva - sua mestria do idioma, sua familiaridade com as formas fixas, sua perícia metrificante, sua incorporação enfim a uma tradição".
} 
gauche na vida" pode ser interpretado como referência a um traidor do latifúndio ${ }^{47}$; o que faz cada vez mais sentido quando se nota que a acepção da palavra é inapto, canhoto, malfeito, vacilante, embaraçado, desajeitado significados que estão (de forma direta ou indireta) no poema "Os bens e o sangue", que é onde Drummond, de acordo com Antonio Candido, "estabelece a ligação entre o passado da família e o presente do indivíduo, através da forma altamente significativa de um testamento" ${ }^{\prime 48}$ :

\begin{abstract}
- Ó meu, ó nosso filho de cem anos depois, que não sabes viver nem conheces os bois pelos seus nomes tradicionais... nem suas cores marcadas em padrões eternos desde o Egito.
\end{abstract}

Ó pobre, e descorçoado, e finito ó inapto para as cavalhadas e os trabalhos brutais com a faca, o formão, o couro... Ó tal como quiséramos para tristeza nossa e consumação das eras, para o fim de tudo que foi grande!

$$
\text { Ó desejado, }
$$

ó poeta de uma poesia que se furta e expande à maneira de um lago de pez e resíduos letais... És nosso fim natural e somos teu adubo, tua explicação e tua mais singela virtude...

Pois carecia que um de nós nos recusasse

\footnotetext{
${ }^{47}$ Cf. Roberto Schwarz, "Cultura e política, 1964-1969", Cultura e política, São Paulo, Paz e Terra, 2009, p. 58: "uma figura representativa da literatura brasileira deste século é o 'fazendeiro do ar': o homem que vem da propriedade rural para a cidade, onde recorda, analisa e critica, em prosa e verso, o contato com a terra, com a família, com a tradição e com o povo que o latifúndio Ihe possibilitara".

${ }^{48}$ Antonio Candido, "Inquietudes na poesia de Drummond", Op. cit., p. 133.
} 
para melhor servir-nos. Face a face

te contemplamos, e é teu esse primeiro

e úmido beijo em nossa boca de barro e sarro.

Uma outra característica relativa à atitude oscilante da figura do gauche é que, mesmo tendo negado a sua formação junto à oligarquia latifundiária itabirana, nunca chegou a aderir de maneira irrestrita aos valores da modernidade. É só pensar no poema "Cota zero", em que o progresso se mistura de uma maneira muito irônica e cerrada com a sociedade em seus mais variados níveis; a ponto de o poeta ter dúvidas se determinados códigos de conduta ("stop") - que seriam de apenas um nível em especial, o trânsito ("automóvel") - não se dirigiriam ao próprio modo de vida na metrópole ("a vida parou"):

\author{
Stop. \\ A vida parou \\ ou foi o automóvel?
}

Sob o viés dos aspectos referidos, é possível observar que a figura do gauche é o espaço por excelência da disposição antagônica da estrutura da realidade brasileira a partir da visão subjetiva do indivíduo. O movimento dialético da obra de Drummond pode até ser resultante de um provável pensamento de esquerda (de acordo com Merquior); só que não é insensato pensar que derive da incorporação do contexto histórico do país-colônia e do país-burguês: por natureza, o artista brasileiro que não recalca as aporias da realidade imediata está fadado a ser um dialético de ofício; é o dever estético e 
político com a história, e não com os ismos que está na base, creio, do movimento dialético de Drummond.

Da disposição antagônica decorre um produto literário dialético e imerso em negatividade: a interiorização da exterioridade por parte da subjetividade (que é o instante lírico por excelência da lírica) integra as aporias do sujeito e da realidade - o que cria uma analogia negativa entre os dois, e torna difícil que a obra esteja isenta da representação das tensões que são próprias de sua estrutura mais profunda.

Daí que a obra de Drummond não encarne uma resposta aos problemas, o que poderia ser encarado como ideologia (falsa consciência no tratamento do material artístico e histórico). É só pensar na estrofe do "Poema de sete faces":

As casas espiam os homens

que correm atrás de mulheres.

A tarde talvez fosse azul,

não houvesse tantos desejos.

Não é difícil apontar que o "azul" da "tarde" seja uma resposta aos problemas, mas é remota e capenga, uma vez que a ênfase está no jogo erótico dos "tantos desejos".

A resposta ("azul”) pode até estar pressuposta na obra de Drummond, mas não se dá diretamente (cf. a condicional em "a tarde talvez fosse") por causa do embate com as aporias e os impasses ("tantos desejos") que a contamina; é o contraponto de um discurso que só se realiza mediante a aprovação da negatividade. 
Se meu verso não deu certo,

foi seu ouvido que entortou.

Eu não disse ao senhor

que não sou senão poeta?

Carlos Drummond de Andrade

- Hypocryte lecteur, - mon semblable,

- mon frère!

Charles Baudelaire

Nas linhas acima, tentei situar a figura do gauche em uma conjuntura específica (20-30), isto é, o juízo girou ao redor do produtor da poesia - ao menos, o seu alter ego, que é o eu lírico. Já nas linhas a seguir, tentarei analisar, por sua vez, o receptor da poesia no período em questão.

De acordo com Ivone Daré Rabello, o cenário literário (obra, autor e leitor) no início do século 20 apontava "a dissociação entre o olhar do artista que extraía poesia das formas pouco nobres e contraditórias da realidade - e o do público tradicional”49. Um outro ponto: a taxa dos que não sabiam ler (ou escrever) em 1920 era de $75 \%{ }^{50}$; dos $25 \%$ restantes, outros poucos $\%$ eram os leitores de poesia, em tese $\mathrm{O}$ cenário literário se enche de drama quando a analista indica que,

em nossas terras, o lugar do poeta nos primeiros decênios do século XX ganha mais

\footnotetext{
${ }^{49}$ Ivone Daré Rabello, Op. cit., p. 110.

${ }^{50}$ Cf. Antonio Candido, "Literatura e cultura de 1900 a 1945”, Op. cit., p. 144.
} 
dramaticidade como representação de nossa vida cultural se pensarmos que, num cenário em que os meios materiais da circulação artística ainda não haviam se universalizado, a poesia permanecia - segundo o modelo do final do século XIX brasileiro - ornamento útil para o verniz burguês ${ }^{51}$.

Em resumo, não era nada fácil, então, a tarefa do artista modernista: o mercado literário estava praticamente limitado ao público burguês, que aspirava ao poder político e econômico, e ao poder espiritual, o qual tinha na arte a sua expressão mais idealizada; só que não a arte moderna, e sim a canônica, de maior prestígio na escala social.

O choque do país-colônia e do país-burguês se dava entre o leitor tradicional e o autor de vanguarda, e entre a obra nova e o cenário cultural incipiente.

Por causa desse cenário, é de esperar que o sucesso de Alguma poesia fosse suspeito, mas é o oposto que se verifica. E a razão, se não me engano, foi o impacto causado por "No meio do caminho",52, que veio à luz em 1928 na Revista da antropofagia, e deixou os leitores curiosos (no mínimo) com o livro de estréia, que sairia dois anos depois. Na já referida biografia do poeta, José Maria Cançado disse que

no dia 30 de abril de 1930 saíram da gráfica 500 exemplares, distribuídos entre amigos do poeta e livrarias. O livro, guardadas todas as proporções, foi um fenômeno de divulgação capaz de ofuscar as grandes campanhas atuais de marketing em torno de alguns lançamentos. Houve até, fenômeno também típico da imprensa cultural, a compulsão do furo, com o Estado

\footnotetext{
${ }^{51}$ Ivone Daré Rabello, Op. cit., p. 110.

${ }^{52} \mathrm{O}$ impacto foi tão forte que deu para Drummond ajuntar as críticas (boas e ruins) no volume Uma pedra no meio do caminho: biografia de um poema, Rio de Janeiro, Editora do Autor, 1967.
} 
de Minas dando a notícia do livro no dia seguinte à sua publicação, furando o próprio jornal em que Drummond trabalhava, o Minas Gerais. Assim, nos primeiros trinta dias depois da aparição de Alguma poesia já tinham sido publicadas quinze críticas em jornais de Belo Horizonte, do Rio, São Paulo, Recife e Porto Alegre (seriam cerca de setenta, contabilizou Arnaldo Saraiva $)^{53}$.

Deu-se então, que Alguma poesia se cercou de apreensão e expectativa: que outras ousadias teria a dizer o poeta da pedra? Antes da publicação do livro, a relação de Drummond com o público já se pautava a partir da provocação.

Do exposto, estabelecemos, creio, um primeiro vínculo da obra de Drummond com o período de 20-30. Outro aspecto é a construção de um retrato mais fiel (isto é, sem distorções ideológicas) do público burguês, um retrato vinculado ao contexto histórico imediato, que o beletrismo da época não era capaz de fazer. De início, vamos acompanhar o poema "Sweet home" para algumas considerações de princípio:

Quebra-luz, aconchego.

Teu braço morno me envolvendo.

A fumaça de meu cachimbo subindo.

Como estou bem nesta poltrona de humorista inglês.

O jornal conta histórias, mentiras...

Ora afinal a vida é um bruto romance

e nós vivemos folhetins sem o saber.

Mas surge o imenso chá com torradas,

${ }^{53}$ José Maria Cançado, Op. cit., 131-32. 
chá de minha burguesia contente.

Ó gozo de minha poltrona!

Ó doçura de folhetim!

Ó bocejo de felicidade!

O objeto do poema é o burguês, ou melhor, a sua caricatura. Já no título, presenciamos a ideologia do "lar doce lar". A "casa" é a imagem do homem privado: vaidoso do seu universo (íntimo) de valores, que traz o "bocejo de felicidade"; alienado da agitação exterior, que chega à sua intimidade como um burburinho (até certo ponto) indiferente - nada pode atrapalhar o "gozo" propiciado pelo estilo de vida do burguês, que está exposto no deleite ("quebraluz, aconchego"), nos objetos ("poltrona”, "cachimbo"), nos hábitos ("chá com torradas").

No cenário burguês, a literatura é prazer ("ó doçura de folhetim"), e não chance de conhecer a realidade brasileira, que poderia interferir na intimidade da "burguesia contente" ao trazer suas aporias e os seus impasses; se o exterior dá as caras (“o jornal conta histórias, mentiras...”), está filtrado por uma burguesa percepção da sociedade, isto é, por uma visão pouco realista dos episódios, que mistura fantasia e realidade ("ora afinal a vida é um bruto romance / e nós vivemos folhetins sem o saber"). Daí que a vida se torne aos olhos do burguês um espetáculo folhetinesco de que pode gozar de sua posição distanciada e privilegiada.

Já nestes breves apontamentos, podemos notar que o poeta vai enumerando ironicamente alguns aspectos do burguês. A caricatura, como é da sua natureza, amplia de tal forma os traços da burguesia que fica difícil segurar o riso por muito tempo. 
É para o sujeito ridículo descrito no poema que se dirige a obra de Drummond, como provocação? A resposta não é tão terra-a-terra assim: é preciso observar antes de mais nada que o poeta constrói mais uma figura-abstrata do que uma figura-concreta do burguês. É um caso similar ao da atitude romântica ante a burguesia que Dolf Oehler analisou:

o artista esquecia facilmente [...] o burguês verdadeiro; parecia ocioso [...] oferecer dele uma visão concreta por intermédio da representação artística ou mesmo elaborar um conceito político do burguês [...] Ele [o romântico] havia muito perdera de vista o burguês real e o substituíra por um burguês-fantasma [...] O ódio mortal do romantismo e da boêmia ao "burguês" não fazia mais do que facilitar as estratégias da burguesia para negar a si mesma como classe [...] O romântico revela-se como burguês justamente em sua fobia ao burguês, pois pensando em ver o burguês por toda a parte, torna-se cego para a burguesia como classe, e, mais ainda, como classe exploradora ${ }^{54}$.

Traçando um paralelo com as idéias do crítico, vemos claramente que "Sweet home" não é um poema notável, uma vez que o tratamento do material artístico distorce e encobre o material histórico que se dispôs a colocar no centro de sua atenção. É só pensar na diferença de qualidade entre a figura do gauche como representação das aporias e impasses da realidade brasileira, e a figura-abstrata do burguês no poema citado: ali o sujeito se sabe parte da classe que deve o seu poder à conservação da estrutura opressora da sociedade - daí a culpa social ${ }^{55}$; aqui a caricatura é antes piada do que crítica

\footnotetext{
${ }^{54}$ Dolf Oehler, Quadros parisienses: estética anti-burguesa em Baudelaire, Daumier e Heine, Trad. José Marcos Macedo / Samuel Titan Jr., São Paulo, Companhia das Letras, 1997, pp. $12-$ 13.

${ }^{55}$ Cf. Vagner Camilo, Op. cit., p. 77: "a agudíssima consciência da distância social que separa o artista ou o intelectual em geral do proletário jamais Ihe permitiu fazer qualquer concessão ao
} 
- o aspecto opressivo da burguesia é deslocado (se não abstraído) em função da revolta ou desgosto ao burguês (o que o transforma em uma figura ridícula; não intimidante) - o que faz que o poema seja inferior tanto nos aspectos estéticos quanto nos políticos.

A obra de Drummond se dirige - como provocação - para o burguês, mas não o descrito no poema acima; por sorte, Alguma poesia traz a sua figura-concreta, que está no poema "Explicação", o qual Mário de Andrade indicou como abertura do livro de estréia antes de conhecer as "sete faces" da figura do gauche:

\author{
Meu verso é minha consolação. \\ Meu verso é minha cachaça. Todo mundo tem sua cachaça. \\ Para beber, copo de cristal, canequinha de folha-de-flandres, \\ folha de taioba, pouco importa: tudo serve. \\ Para louvar a Deus como para aliviar o peito, \\ queixar desprezo da morena, cantar minha vida e trabalhos \\ é que faço meu verso. E meu verso me agrada.
}

Meu verso me agrada sempre...

Ele às vezes tem o ar sem-vergonha de quem vai dar uma cambalhota, mas não é para o publico, é para mim mesmo essa cambalhota.

populismo. Ao contrário, fez dessa distância - sempre permeada, como veremos, de um implacável sentimento de culpa - a matéria mesma de que se alimentam alguns de seus mais belos poemas". Na mesma página, o crítico diz que Drummond endossa o que Benjamin afirmara em 30: "'a esquerda radical [...] jamais abolirá o fato de que mesmo a proletarização do intelectual quase nunca fará dele um proletário', já pelo acesso privilegiado à cultura, que '[...] o torna solidário com ela e, mais ainda, a torna solidária com ele. Essa solidariedade pode até ser apagada na superfície, ou até dissolvida; mas quase sempre ela permanece suficiente forte para excluir de vez o intelectual do estado de prontidão constante e da existência do verdadeiro burguês'”. 
Eu bem me entendo.

Não sou alegre. Sou até muito triste.

A culpa é da sombra das bananeiras de meu país, esta sombra mole, preguiçosa.

há dias em que ando na rua de olhos baixos

para que ninguém desconfie, ninguém perceba

que passei a noite chorando.

Estou no cinema vendo fita de Hoot Gibson,

de repente ouço a voz de uma viola...

saio desanimado.

Ah, ser filho de fazendeiro!

À beira do São Francisco, do Paraíba ou de qualquer córrego vagabundo,

é sempre a mesma sen-si-bi-li-da-de.

E a gente viajando na pátria sente saudades da pátria.

Aquela casa de nove andares comerciais

é muito interessante.

A casa colonial da fazenda também era...

No elevador penso na roça,

na roça penso no elevador.

Quem me fez assim foi minha gente e minha terra

e eu gosto bem de ter nascido com essa tara.

Para mim, de todas as burrices a maior é suspirar pela Europa.

A Europa é uma cidade muito velha onde só fazem caso de dinheiro

e tem umas atrizes de pernas adjetivas que passam a perna na gente.

O francês, o italiano, o judeu falam uma língua de farrapos.

Aqui ao menos a gente sabe que é tudo uma canalha só,

lê o seu jornal, mete a língua no governo,

queixa-se da vida (a vida está tão cara)

e no fim dá certo.

Se meu verso não deu certo, foi seu ouvido que entortou.

Eu não disse ao senhor que não sou senão poeta? 
O título já tem anotada a fórmula de construção do poema, que opera para trazer a "explicação": os versos são longos para estender as idéias; as partículas conectivas estão aqui e ali; por trás das imagens, vibra a presença de conceitos e conteúdos; os versos são retomados e expandidos.

De início, a sensação é de que só está em pauta o poeta, que busca apontar de que é feita a sua poesia - tanto na forma ("para beber, copo de cristal, canequinha de folha-de flandres, / folha de taioba) quanto no conteúdo ("para louvar a Deus como para aliviar o peito, / queixar o desprezo da morena, cantar minha vida e trabalhos / é que faço meu verso"): trata-se de uma colcha de retalhos, em que "tudo serve".

O leitor é provocado no verso 10 ("mas não é para o publico, é para mim mesmo essa cambalhota"), pois a "cachaça", a "consolação" e a "cambalhota" são de domínio privado; as quais servem para confortar a tristeza que tem raízes na realidade brasileira ("não sou alegre. Sou até muito triste. / A culpa é da sombra das bananeiras do meu país, esta sombra mole, preguiçosa") - de acordo com Alcides Villaça, a explicação sociológica aqui está ligada a "um caráter nacional identificável como indolente, inzoneiro, melancólico, cordial, sentimental, em suma: legítimo produto das 'três raças tristes"”56.

A tristeza é funda a ponto de o instante de diversão não ser capaz de consolar ("estou no cinema vendo fita de Hoot Gibson, / de repente ouço a voz de uma viola... / saio desanimado"). Na verdade, a tristeza chega até a se alargar, uma vez que o poeta é um desterrado da sua própria terra como tantos outros que a expressão "a gente" indica com perfeição ("e a gente viajando na pátria sente saudades da pátria"): o desterro parece estar ligado à configuração

\footnotetext{
${ }^{56}$ Alcides Villaça, Passos de Drummond, São Paulo, Cosac Naify, 2006, p. 45.
} 
contraditória da realidade brasileira, a qual não dá um paradigma coerente para o indivíduo; o país é ainda uma imagem desfocada, que "a gente" encara com familiaridade ("na pátria") e com estranheza ("sente saudades da pátria"). Se o poeta e o leitor partilham a mesma conjuntura, é uma afronta não dar ao outro o prazer do consolo que a poesia traz: a realidade brasileira (raiz da tristeza) é um cenário de opostos que não acha o equilíbrio apropriado entre o paíscolônia e o país-burguês ("no elevador penso na roça, / na roça penso no elevador").

O cenário é bizarro; apesar disso, o poeta ainda tenta fazer uma argumentação para louvar o país: de início, enumera alguns motivos para odiar o velho continente ("de todas as burrices a maior é suspirar pela Europa. / A Europa é uma cidade muito velha onde só fazem caso de dinheiro / e tem umas atrizes de pernas adjetivas que passam a perna na gente. / $O$ francês, o italiano, o judeu falam uma língua de farrapos"); depois, insere uma explicação - sem muita lógica, na verdade - para louvar o país ("Aqui ao menos a gente sabe que é tudo uma canalha só, / lê o seu jornal, mete a língua no governo, / queixa-se da vida (a vida está tão cara) / e no fim tudo dá certo"). De acordo com Alcides Villaça, o que se tem nos versos é o

axioma nacional do "no fim dá certo" - misto de malandragem e escatologia cristã. / A argumentação é brilhante, desconcertante, sem fugir um milímetro de uma espécie de filosofia do senso comum do brasileiro pouco instruído, ou então daqueles instruídos que a sabem apresentar como boa ideologia. O efeito geral desses versos lembra o de alguns irônicos textos machadianos, em que fica difícil se divertir até o fim com a jocosidade de base grave e realista ${ }^{57}$.

\footnotetext{
${ }^{57}$ Idem, p. 46.
} 
A provocação que o poeta dirige ao público chega ao extremo nos versos finais (se meu verso não deu certo, foi seu ouvido que entortou. / Eu não disse ao senhor que não sou senão poeta?); é agora direto o insulto, em que, ainda de acordo com Alcides Villaça,

a possibilidade de o poema no fim "não dar certo" já é tratada como um fato, cujo prejuízo se desloca e se debita do lado do leitor: um outro para esse eu que não é "senão poeta". Imputando a esse outro lado a tortuosidade que costumava ver em si mesmo, o sujeito poético mina as certezas conservadoras do "verso certo" (sendo difícil esquecermos o que havia de canônico, de belles lettres e de oficialismo na poesia dominante da época), afirma uma espécie de nova afinação para a poesia e, dentro do restritivo - "não sou senão poeta" -, garante-se um espaço de liberdade imprevista. Vê-se logo que a discrepância estética é mais do que isso: trata-se de um movimento novo, certamente modernista, mas também muito pessoal, em que os versos já não se restringem à pura "consolação", mas adotam a crítica e o humor que deixam muito deslocada a ideologia do senso e que, sem exaltar o lugar do poeta, tornam ridículas as expectativas do leitor convencional. A operação lembra muito a de Baudelaire e seu "hypocrite lecteur", atualizada e particularizada nas condições peculiares deste mineiro e de seu público ${ }^{58}$.

A provocação - que vai desde as formas sutis da piada até o sarcasmo mais acentuado - dá o tom ao poema: aos poucos, ela vai descortinando uma imagem do público burguês condizente com o contexto histórico imediato, que é o mesmo do poeta. É a este leitor que o poeta dirige a sua obra. Há uma afinidade estrutural entre os dois (decorrente da realidade brasileira) que Drummond deu conta de expor. De acordo com Antonio Candido, "o eu estrangulado é em parte conseqüência, produto das circunstâncias; se assim

\footnotetext{
${ }^{58}$ Idem, p. 47.
} 
for, o eu torto do poeta é igualmente uma espécie de subjetividade de todos, ou de muitos, no mundo torto"59.

Por causa da afinidade estrutural, a palavra subjetiva do poeta se converte em verdade objetiva (Carpeaux) para aquele que a lê: a figura do gauche é o espelho em que o leitor pode se mirar, e divisar a realidade brasileira que está na base de sua constituição.

${ }^{59}$ Antonio Candido, "Inquietudes na poesia de Drummond", Op cit., p. 127. 


\title{
Leitura de "Morte do leiteiro"
}

\author{
A poesia fugiu dos livros, agora está nos \\ jornais.
}

Drummond

A epígrafe já aponta para o teor de "Morte do leiteiro": o seu título e o seu enredo poderiam ser confundidos, respectivamente, com a manchete e o conteúdo de uma crônica policial.

Só que o tratamento que o poeta confere à sua matéria dá a esta uma dignidade que está ausente no caráter informativo e às vezes sensacionalista de alguns jornais; é por causa desse tratamento que a narrativa do leiteiro se transforma em uma mini-epopéia da vida na modernidade ${ }^{60}$ : à arenga midiática do "a vida como ela é" (que só atinge a superfície dos fatos), Drummond opõe a imersão profunda no contexto histórico, descortinando sentidos encobertos na realidade brasileira:

\footnotetext{
Há pouco leite no país,

é preciso entregá-lo cedo.

Há muita sede no país,

é preciso entregá-lo cedo.

Há no país uma legenda,
}

\footnotetext{
${ }^{60}$ Cf. Antonio Candido, "Inquietudes na poesia de Drummond", Op. cit., p. 129: o poeta "procede a uma fecundação e a uma extensão do fato, para chegar a uma espécie de discreta epopéia da vida contemporânea"
} 
que ladrão se mata com tiro.

Então o moço que é leiteiro, de madrugada com sua lata sai correndo e distribuindo leite bom para gente ruim. Sua lata, suas garrafas e seus sapatos de borracha vão dizendo aos homens no sono que alguém acordou cedinho e veio do último subúrbio trazer o leite mais frio e mais alvo da melhor vaca para todos criarem força na luta brava da cidade.

Na mão a garrafa branca não tem tempo de dizer as coisas que Ihe atribuo nem o moço leiteiro ignaro, morador na Rua Namur, empregado no entreposto, com 21 anos de idade, sabe lá o que seja impulso de humana compreensão.

E já que tem pressa, o corpo vai deixando à beira das casas uma apenas mercadoria.

E como a porta dos fundos 
também escondesse gente

que aspira ao pouco de leite

disponível em nosso tempo,

avancemos por esse beco,

peguemos o corredor,

depositemos o litro...

Sem fazer barulho, é claro,

que barulho nada resolve.

Meu leiteiro tão sutil

de passo maneiro e leve,

antes desliza que marcha.

É certo que algum rumor

sempre se faz: passo errado,

vaso de flor no caminho,

cão latindo por princípio,

ou um gato quizilento.

E há sempre um senhor que acorda,

resmunga e torna a dormir.

Mas este acordou em pânico

(ladrões infestam o bairro),

não quis saber de mais nada.

O revólver da gaveta

saltou para sua mão.

Ladrão? se pega com tiro.

Os tiros na madrugada

liquidaram meu leiteiro.

Se era noivo, se era virgem.

se era alegre, se era bom, 
não sei,

é tarde para saber.

Mas o homem perdeu o sono

de todo e foge pra rua.

Meu Deus, matei um inocente.

Bala que mata gatuno

também serve pra furtar

a vida de nosso irmão.

Quem quiser que chame médico,

polícia não bota a mão

neste filho de meu pai.

Está salva a propriedade.

A noite geral prossegue,

a manhã custa a chegar,

mas o leiteiro

estatelado, ao relento,

perdeu a pressa que tinha.

Da garrafa estilhaçada,

no ladrilho já sereno

escorre uma coisa espessa

que é leite, sangue... não sei.

Por entre objetos confusos,

mal redimidos da noite,

duas cores se procuram,

suavemente se tocam,

amorosamente se enlaçam,

formando um terceiro tom

a que chamamos aurora. 
De certa forma, o poeta se esconde atrás da máscara do narrador: a técnica narrativa usada no poema serve para dar a impressão de maior objetividade ao relato, já que cria a sensação de distanciamento e imparcialidade em relação à matéria elaborada (no caso, a narrativa do leiteiro), como se o poeta portasse uma câmera e se limitasse a registrar os fatos; na abertura do poema, por exemplo, predominam as orações impessoais e imperativas; aparentemente, nenhum sinal da voz lírica central:

\footnotetext{
Há pouco leite no país,

é preciso entregá-lo cedo.

Há muita sede no país,

é preciso entregá-lo cedo.

Há no país uma legenda,

que ladrão se mata com tiro.
}

A análise da estrofe aponta que os versos 1 e 3 trazem a oposição entre "pouco leite" e "muita sede", estando ligados pelo paralelismo sintático; o verso 5 teria a mesma sintaxe dos versos citados, não fosse a inversão dos termos da oração ("no país" e "uma legenda"); por sua vez, os versos 2 e 4 são idênticos - e explanam uma espécie de advertência do dever do leiteiro; só no verso 6 parece haver informação semântica e formal nova.

A carência de informação faz com que a leitura se volte para os escassos elementos que se diferenciam: nos versos 1 e 3 , "pouco leite" e "muita sede"; no verso 5, "legenda" e, em virtude da inversão sintática, "no país". No entanto, a disposição do sistema métrico demonstra que a variação, ao invés de enfraquecer, reforça a repetição - como é possível notar 
no esquema que transcrevo a seguir:

$\begin{array}{ccccccccc}1 & 2 & 3 & 4 & 5 & 6 & 7 & & \\ \underline{\text { Há }} & \text { pou } & \text { co } & \underline{\text { lei }} & \text { te } & \text { no } & \text { pa } & \underline{i s} & \\ \underline{\text { Há }} & \text { mui } & \text { ta } & \underline{\text { se }} & \text { de } & \text { no } & \text { pa } & \underline{\text { ss }} & \\ \underline{\text { Há }} & \text { no } & \text { pa } & \underline{\text { ś }} & \text { u } & \text { ma } & \text { le } & \underline{g e n} & d a\end{array}$

A estrofe é construída a partir da repetição - com sutis e ligeiras variações aqui e ali. Não é difícil pensar que tal fato se deva à própria natureza do discurso poético: no caso, o uso da métrica de sete sílabas na composição da estrofe; e a reincidência dos versos 2 e 4, que funcionam como uma espécie de estribilho. Por outro lado, não parece ser um exagero assinalar que a repetição - formal e semântica; impessoal e imperativa - da estrofe seja a representação de uma linguagem estratificada, ou por outra, de uma linguagem de poder: o discurso da ditadura.

Do ponto de vista dos estudos lingüísticos, Roland Barthes apontou que todo discurso é um discurso de poder - não só no seu conteúdo, sobretudo na sua estrutura lingüística:

a linguagem é uma legislação, a língua é seu código. Não vemos o poder que reside na língua porque esquecemos que toda língua é uma classificação, e que toda classificação é opressiva: ordo quer dizer, ao mesmo tempo, repartição e cominação. Jákobson mostrou que um idioma se define menos pelo que ele permite dizer do que por aquilo que ele obriga a dizer. Em nossa língua francesa (e esses são exemplos grosseiros), vejo-me adstrito a colocar-me primeiramente como sujeito, antes de enunciar a ação que, desde então, será apenas meu atributo: o que faço não é mais do que a conseqüência e a consecução do que sou; da mesma maneira, sou obrigado a escolher sempre entre o masculino e o feminino, o neutro e 0 
complexo me são proibidos; do mesmo modo, ainda, sou obrigado a marcar minha relação com o outro recorrendo quer ao $t u$, quer ao vous: o suspense afetivo ou social me é recusado. Assim, por sua própria estrutura, a língua implica uma relação fatal de alienação. Falar, e com maior razão discorrer, não é comunicar, como se repete com demasiada freqüência, é sujeitar: toda língua é uma reição generalizada ${ }^{61}$.

O lingüista insiste que a "prática da escrita", isto é, do jogo, da trapaça com a estrutura lingüistica - "no esplendor de uma revolução permanente da linguagem" - é que abre a possibilidade de ouvir a língua livre do discurso de poder.

Traçando um paralelo das idéias acima com a estrofe de "Morte do leiteiro", é possível dizer que o poeta incorpora e reelabora a ideologia totalitária para desmascarar a sua pretensa lógica, para desautomatizar a sua e a nossa percepção do contexto histórico - como pretendo assinalar nas linhas abaixo.

A estrofe apresenta um discurso da carência (vv. 1-4), que traz uma lógica interna, imitando a estrutura de um silogismo: "há pouco leite no país" (premissa 1) e "há muita sede no país" (premissa 2), logo "é preciso entregá-lo cedo (conclusão). Só que essa lógica não se sustenta até o fim da estrofe, pois não tem transitividade semântica com os versos 5 e 6, que são uma espécie de discurso da ordem; em outros termos, sob um momento de verdade (discurso da carência) a ideologia autoritária esconde um momento de mentira (discurso da ordem). A sua falta de sentido é suprida por uma retórica impessoal e imperativa, que procura se impor através de um monótono som reincidente: a repetição da estrutura entre os versos.

\footnotetext{
${ }^{61}$ Roland Barthes, Aula, São Paulo, Cultrix, 1994, pp. 12-13.
} 
A desautomatização da percepção imanta o poema com diversas tensões; por exemplo, o elemento que abre a narrativa propriamente dita ("então") passa a ter um caráter ambíguo: por um lado, transmite a idéia de relação lógica, ligando-se ao imperativo da estrofe anterior; por outro, é quase possível ouvir a ironia do eu lírico que se insinua por trás da linguagem de poder:

\author{
Então o moço que é leiteiro, \\ de madrugada com sua lata \\ sai correndo e distribuindo \\ leite bom para gente ruim. \\ Sua lata, suas garrafas \\ e seus sapatos de borracha \\ vão dizendo aos homens no sono \\ que alguém acordou cedinho \\ e veio do último subúrbio \\ trazer o leite mais frio \\ e mais alvo da melhor vaca \\ para todos criarem força \\ na luta brava da cidade.
}

A sensação é de que "o trabalho enobrece o leiteiro", já que o seu ofício é que torna possível a "luta brava na cidade"; mas, no seu anseio de validade universal, a ideologia subjacente à frase não tinha em conta que "o trabalho [desumanizado] não enobrece o leiteiro". A construção do personagem é, na verdade, uma desconstrução, já que parte de uma fase da vida ("moço"), que depois é restrita ao rótulo da profissão ("que é leiteiro"), para acabar na sua definição por meio dos objetos de trabalho, que são personificados para 
realçar, por contraste, a sua reificação ("sua lata, sua garrafa / e seus sapatos de borracha / vão dizendo"). A caracterização do personagem a partir da mercadoria obscurece o seu sentido humano para indicar a impossibilidade da sua representação fora do trabalho que deve desempenhar perante a sociedade (fora do imperativo presente na primeira estrofe). Nem os versos

\footnotetext{
morador na Rua Namur, empregado no entreposto, com 21 anos de idade
}

conseguem conferir humanidade ao leiteiro, pois parecem com uma ficha burocrática: idade, local de trabalho, endereço - expressar o personagem é incorrer na descrição tipificada.

A reificação do leiteiro tem um correlato no apagamento do seu espaço social ("e veio do último subúrbio"), já que o termo "subúrbio" vem do latim sub + urbs - sob a cidade.

No curso da narrativa, o poeta se transforma em um "nós": a ação se intensifica paralelamente ao estreitamento do espaço, o que talvez indique a dificuldade da vida na cidade grande (os caminhos para o poeta são sempre cheios de pedras). De certa forma, a consciência do eu lírico - sempre insinuante no discurso da ditadura - é o contraponto da "gente escondida na porta dos fundos", isto é, os dois só aparecem na narrativa de forma mediada pela linguagem autoritária, que promove uma espécie de estratégia de silenciamento ("sem fazer barulho, é claro, / que barulho nada resolve"):

E como a porta dos fundos 
também escondesse gente

que aspira ao pouco de leite

disponível em nosso tempo,

avancemos por esse beco,

peguemos o corredor,

depositemos o litro...

Sem fazer barulho, é claro,

que barulho nada resolve.

A experiência na modernidade é difícil para o leiteiro, já que os obstáculos a serem superados assumem os aspectos mais variados possíveis: são internos ("passo errado") e externos ao indivíduo ("vaso de flor no caminho", etc); além do descaso do contato social que adquire uma representação na figura do senhor ("e há sempre um senhor que acorda, / resmunga e torna a dormir"). Ora, se o leiteiro é impelido a realizar o seu trabalho entre o discurso da carência e o discurso da ordem, o "senhor" é impelido a realizar os seus atos por causa do pânico e de uma ideologia que o condiciona a assassinar aqueles que estão à margem da sociedade, ou melhor, aqueles que não praticam uma norma de conduta socialmente aceita e desejada pelo grupo social (“ladrões infestam o bairro”):

\footnotetext{
Mas este acordou em pânico

(ladrões infestam o bairro),

não quis saber de mais nada.

O revólver da gaveta

saltou para sua mão.

Ladrão? se pega com tiro.

Os tiros na madrugada
} 
liquidaram meu leiteiro.

Se era noivo, se era virgem.

se era alegre, se era bom,

não sei,

é tarde para saber.

A percepção do "senhor" é automatizada: o sabor coloquial de sua fala ("Ladrão? se pega com tiro") não esconde que a atitude pessoal é, de fato, impessoal, pois a atitude do indivíduo é a reposição da ideologia da sociedade que está no verso 6: "ladrão se mata [pega] com tiro".

Nesse ponto da estrofe, as possíveis características mais marcadamente humanas do personagem ("noivo", "virgem", "alegre", "bom”) são postas em pauta através das condicionais: meras virtualidades de ser, que a narrativa não pode expressar ("não sei").

Na seqüência do poema, surgem vários versos que imprimem um ritmo frenético à narração, parecendo expressar a simultaneidade de vozes (a autonomia das frases dá a impressão de várias vozes que somente estão dispostas linearmente devido à natureza da palavra escrita):

Meu Deus, matei um inocente.

Bala que mata gatuno

também serve pra furtar

a vida de nosso irmão.

Quem quiser que chame médico,

polícia não bota a mão

neste filho de meu pai.

Está salva a propriedade. 
De maneira análoga à incorporação do discurso da ditadura, o poeta se apropria de várias vozes sociais para desvelar o seu caráter ideológico: por exemplo, a pretensa caridade do apelo ao "médico" parece esconder, na verdade, o receio da "polícia"; e o verso "está salva a propriedade" é uma reposição do verso "ladrão se mata com tiro". No entanto, creio que a crítica mais interessante está ligada ao fato de o eu lírico transferir a máscara de ladrão do leiteiro para o senhor, o que é feito mediante um artifício habilidoso: a utilização do verbo "furtar" para qualificar o seu ato. Drummond mostra que o senhor (provavelmente um membro da burguesia) é o ladrão, uma vez que a conservação da estrutura de poder da classe dominante foi fruto da modernização conservadora que esteve alheia aos anseios da categoria operária. Sob esse viés, a "rua" é o espaço que define, atenua ou redime o ato individual e suicida por encarnar a estrutura da sociedade.

Nos versos finais, a analogia entre o "leite" e o "sangue" se desdobra em uma cosmogonia (de certo apelo erótico) para criar a imagem da "aurora". A respeito desses versos, há pelo menos duas interpretações possíveis:

Da garrafa estilhaçada,

no ladrilho já sereno

escorre uma coisa espessa

que é leite, sangue... não sei.

Por entre objetos confusos,

mal redimidos da noite,

duas cores se procuram,

suavemente se tocam,

amorosamente se enlaçam, 
formando um terceiro tom

a que chamamos aurora.

Em uma primeira interpretação, é viável dizer que o eu lírico passou por cima das aporias da realidade brasileira por causa do tratamento dirigido à forma estética: sobre a "morte do leiteiro", a "aurora" é incapaz de modificar, de fato, a existência que a criou. Se for esse o caso, a minha crítica não é para rebaixar a obra de Drummond, pois não atinge o que essa obra tem de notável, assim como o meu elogio em nada serve para celebrar uma obra que de resto não precisa dele; mas é válida por mostrar que a relação que o poeta tem com a objetividade se fundamenta justamente na representação das aporias do material histórico e artístico, sem cair para a estetização ou para a reificação.

Por outro lado, a segunda interpretação da estrofe se dirige ao fato de que o poeta tomou de empréstimo certo discurso social que já foi visto na análise de "Explicação": o final feliz, a escatologia cristã, etc. Vale a pena repetir: nesse poema o eu lírico tratou o tema de forma satírica, provocando a sensibilidade do leitor, ou melhor, a ideologia brasileira do "no fim tudo dá certo". Já no poema que aborda a "morte do leiteiro" a questão era mais trágica: essa ideologia revela a sua face mais perversa; não havia saída humorística. Sob esse viés, é possível rever a primeira interpretação: o poeta teve de projetar na superfície da estrofe a ideologia brasileira do "no fim tudo dá certo", correndo o risco de sofrer distorções ideológicas (estetização), para apontar de forma explícita a sua perversidade.

Dado o grau de consciência da obra drummondiana, é de se supor que a segunda interpretação seja mais pertinente, pois o poeta provavelmente não 
incorreria no erro de sublimar as aporias do contexto histórico; ao contrário, a representação dessas aporias tem o seu exemplo mais sintomático na estrofe inicial: o eu lírico se apropria de um discurso marcadamente totalitário (o qual é construído a partir de frases impessoais e imperativas que têm por base a repetição de estruturas lingüísticas para aumentar a eficácia da assimilação do conteúdo que se quer propagar); a seguir, revela o sem-sentido em que se fundamenta: é uma relação baseada na retórica, e não na lógica.

É de maneira notável que Drummond incorpora a repetição autoritária para - com uma sutil variação dos versos 5 e 6 - revelar a estrutura de persuasão do discurso da ordem, atacando este no que tem de mais característico, ou por outra, afirmando a repetição como procedimento propriamente poético, a fim de apontar a verdade dos fatos justamente no momento em que os retira da manipulação ideológica.

Talvez essa estrofe seja o ponto alto de poema: trata-se de um poeta dono do seu ofício; que fica à vontade mesmo em terreno inimigo; incorporando procedimentos, trabalhando materiais, comparando estruturas, relativizando conceitos e juízos.

Já em outros pontos do poema, a tensão é um pouco mais baixa, o que talvez seja um reflexo, no plano poético, do estado de sítio da sociedade. No entanto, esse fato parece estar mais relacionado à posição assumida pelo sujeito poético: já foi dito que a máscara do narrador é uma estratégia para criar a impressão de uma maior objetividade ao relato, devido à sensação de distanciamento e imparcialidade em relação à matéria a ser trabalhada; por outro lado, parece ser possível cogitar que essa posição distanciada traz um certo impasse ao poema, uma vez que dá a sensação de se tratar do olhar de 
cima do intelectual.

Em outras páginas, foi dito que um dos aspectos notáveis da obra de Drummond é o fato de a figura do gauche incorporar a realidade brasileira a partir de uma afinidade estrutural entre ambas (no caso, o movimento antagônico da estrutura mental e social), o que criou uma imagem do contexto histórico que se dá de acordo com o ponto de vista do poeta, que se sente mais à vontade em fazer girar as aporias e os impasses na própria subjetividade, ao invés de tratá-los como matéria bruta e, portanto, exterior. O que quero dizer é que às vezes a posição distanciada do narrador (que é a força e a fraqueza de "Morte do leiteiro") é um obstáculo para a incorporação do contexto histórico, e da representação de suas tensões mais profundas: era um problema menos pessoal; portanto, menos poético.

É um caso diferente do que acontece, por exemplo, em "O operário no mar", em que a distância entre o poeta e o operário repercute na consciência lírica como culpa social; o drama é interno; por isso a tensão, mais neste poema do que naquele:

Para onde vai o operário? Teria vergonha de chamá-lo meu irmão. Ele sabe que não é, nunca foi meu irmão, que não nos entenderemos nunca. E me despreza... Ou talvez seja eu próprio que me despreze a seus olhos. 


\section{Leitura de "Oficina irritada"}

No ensaio que tratou dos anos 20-30, vimos como o vínculo de Drummond com o público se estabeleceu a partir do uso da provocação. No caso de "Oficina irritada", a provocação assume os contornos mais nítidos de violência. De acordo com Antonio Candido, um dos pontos principais da obra drummondiana é

a violência -, que, partindo do prosaísmo e do anedótico nos primeiros livros, se acentua a ponto de exteriorizar a compulsão interna, num verdadeiro choque contra o leitor. À maneira de Graciliano Ramos no romance, Drummond, na poesia, não procura ser agradável, nem no que diz, nem na maneira por que o diz ${ }^{62}$.

Feitas essas indicações de princípio, é preciso ver de perto a composição do poema:
Eu quero compor um soneto duro
como poeta algum ousara escrever
Eu quero pintar um soneto escuro,
seco, abafado, difícil de ler.

Quero que meu soneto no futuro

\footnotetext{
${ }^{62}$ Antonio Candido, "Inquietudes na poesia de Drummond”, Op. cit., p. 144.
} 
não desperte em ninguém nenhum prazer.

E que, no seu maligno ar imaturo,

ao mesmo tempo saiba ser, não ser.

Esse meu verbo antipático e impuro

há de pungir, dá de fazer sofrer,

tendão de Vênus sob o pedicuro.

Ninguém o lembrará, tiro no muro

cão mijando no caos, enquanto Arcturo,

claro enigma, se deixa surpreender.

De início, é preciso enumerar alguns aspectos formais do poema: os versos medidos (decassílabos), a forma fixa (soneto), o uso constante das rimas, as imagens mitológicas, a sintaxe com um quê de clássica. Em outros momentos da sua obra, Drummond usou esses procedimentos; no entanto, é em Claro enigma que parecem formar um sistema mais organizado de técnicas poéticas.

Para Vagner Camilo, a reclassicização do verso drummondiano está diretamente inscrita em uma tendência da época: "a especialização do trabalho artístico-literário" no pós-guerra, que visava à criação de um campo autônomo para a literatura. $O$ crítico aponta ainda que essa tendência não fez com que o poeta itabirano incorresse na ilusão da "completa autonomia da arte, que levaria muitos dos poetas de 45 a um novo enclausuramento na torre-demarfim"63. Ao contrário, Drummond se utilizou do conhecimento técnico como uma estratégia de pesquisa constante das possibilidades de representação do

\footnotetext{
${ }^{63}$ Vagner Camilo, Op. cit., p. 58.
} 
contexto histórico, o que traduziria a inserção de uma postura ética e participativa na postura estética.

No caso de "Oficina irritada", o próprio título traz a referência à crescente divisão do trabalho intelectual (ao domínio sobre o material artístico): trata-se de um profissional que, em sua "oficina", pesa a sua matéria-prima, encontra soluções, lapida a criação. O poema aparece como um ato da vontade do produtor, que o quer desta, e não daquela maneira: na primeira estrofe, o verbo "quero" (usado duas vezes) indica esse fato. A ênfase no domínio sobre o material de trabalho faz com que até mesmo os problemas possíveis na construção do poema sejam vistos como resultados (desejados) da vontade do poeta: por exemplo, a imaturidade ("no seu maligno ar imaturo") e a ambigüidade ("saiba ser, não ser").

Do ponto de vista da postura ética de que trata Camilo, é preciso ver de perto o conteúdo violento que o poema dirige ao público. De que público se trata aqui? É nomeado duas vezes sob o signo de "ninguém": de certa forma, o poeta polemiza com a tríade autor-obra-leitor, tirando este último de cena como parte do sistema literário, e se concentra no autor e na obra - daí a ênfase na realização do trabalho, e a presença constante de marcas de primeira pessoa no decorrer do poema.

Então, o sucesso de "Oficina irritada" independe da reação do público? É unicamente resultado da habilidade do artífice em concretizar a sua obra de acordo com um projeto traçado? Creio que a questão aqui é outra, pois não pode haver sistema literário sem a tríade citada: sem o leitor, a obra é apenas um monólogo do poeta consigo mesmo. O leitor (à primeira vista descartado) está implicado de alguma maneira na obra. O lingüista Emile Benveniste disse 
certa vez que a subjetividade na linguagem se faz a partir de dois elementos: o eu e o tu, que são elementos dêiticos, isto é, são estruturas vazias que só adquirem referência precisa no ato da enunciação. Daí que possam ser intercambiáveis durante o processo comunicativo. Em outros termos, eu só posso me dirigir como eu a alguém que, no meu discurso, será um tu; por sua vez, quando o outro assume a palavra, as posições se trocam - essa dinâmica é que torna possível o diálogo e a noção de subjetividade.

A exclusão do leitor em "Oficina irritada" implica, então, não só a problematização do sistema literário, mas também põe em cheque a própria possibilidade de subjetividade do eu lírico. Sob esse viés, a violência do poeta contra o público se volta contra si mesmo: se a violência se processa como automutilação do sujeito no plano individual, ela se torna provocação ao público no plano da recepção. O risco da perda do teor subjetivo da experiência talvez explique a presença constante das marcas da primeira pessoa no poema, isto é, o eu lírico expõe reiteradamente a sua posição por causa das aporias e dos impasses advindos da exclusão do outro, do público: em "eu quero", por exemplo, a primeira pessoa gramatical é redundante; aparece tanto no pronome quanto na terminação verbal.

Tendo em mente esses aspectos, é possível reinterpretar o título do poema: sem o outro, que traz a noção de subjetividade ao eu lírico, só resta a este adjetivar a "oficina", personificando-a. O próprio poeta se vê excluído da expressão poética: as marcas de primeira pessoa são vazias, esperando para serem preenchidas.

De certa forma, a violência de Drummond contra o público parece estar relacionada com a crítica à estrutura do sistema literário da época. Em 1944, o 
poeta deu uma entrevista a Homero de Senna, na qual tratou ironicamente a relação do escritor com o mercado cultural:

[...] hoje o literato não só se faz e se quer muito interessado, do ponto de vista social e político, como ainda as condições do mercado o tornam "interessado" economicamente, isto é, o situam numa nova profissão, a de escritor, e lhe determinam uma produção ao gosto do público, mais ou menos como a da roupa, dos objetos elétricos, de tudo que se compra e vende por aí... ${ }^{64}$

No seu livro Quadros parisienses: estética antiburguesa em Baudelaire, Daumier e Heine, Dolf Oehler trouxe um argumento bastante interessante de Baudelaire sobre a relação entre o artista e o mercado artístico que vigorava na França de então, e que pode ajudar a ver a especificidade de Drummond no que diz respeito a essa questão. Na perspectiva do poeta francês,

o primeiro passo para se permanecer fiel à realidade é a percepção das modificações radicais nas condições de produção da arte e o estudo do mercado e da dialética em que este envolve o artista. A arte é mercadoria, a literatura um negócio como outro qualquer, que deve abrir falência se for exercida sem cálculo, energia, ritmo, iniciativa, diplomacia e persistência. Nada mais diferencia o poeta do jornalista; o que Balzac continuava a reverberar - a corrupção do talento através da imprensa - passa a ser aceito sem queixas. De que adiantaria, aliás, opor-se ao ineludível? O fracassado é apenas ridículo. A mercadoria literária que ninguém compra não porta o selo de qualidade romântico guignon - incompreensão fatal do gênio numa sociedade pouco intelectualizada -, mas antes o duvidoso título honorífico de "encalhado". A questão da qualidade da obra só surge quando esta tem boa aceitação. Mas para isso é necessária uma "originalidade voltada para o mercado". Para ser competitivo, deve-se ter um cuidado especial com a fachada do produto artístico, cuja qualidade não é perceptível à primeira vista por um

${ }^{64}$ Carlos Drummond de Andrade apud Homero de Senna, "Poética moderna", Org. Sônia Brayner, Op. cit., p. 23. 
público burguês pouco dado às artes: deve-se emitir sinais que atraíam os compradores, do mesmo modo que a prostituta destaca-se da femme honnête pela maquiagem e pelas lantejoulas ${ }^{65}$.

A ênfase de Oehler está em observar na atitude de Baudelaire a estética antiburguesa,

que pressupõe que o artista/escritor oriente a sua estratégia de público inteiramente pela burguesia, no sentido de que esta é ao mesmo tempo destinatária - a obra será como que "maquiada" para ela - e alvo - se possível, sem que ela própria a perceba ${ }^{66}$.

Traçando uma aproximação dos elementos estudados até aqui de "Oficina irritada" com a frase de Drummond citada mais acima, talvez seja possível dizer que as novas condições de produção e recepção da arte implicavam praticamente a anulação da consciência lírica em função do gosto do público. Polemizando com o mercado cultural, o poeta procura agredir, e não agradar o leitor, que é até mesmo retirado de cena no poema, o que tem como contraponto (conforme foi exposto) a problematização da noção de subjetividade lírica, gerando um sistema de violências mútuas. O sentido da relação de Drummond com público é oposto ao de Baudelaire: a sua crítica é direta, e não indireta (como no poeta francês); inclusive no fato da fachada da sua obra (a reclassicização do verso drummondiano) ir contra o gosto de um leitor que, na época, já estava acostumado e à vontade com as formas da

\footnotetext{
${ }^{65}$ Doelf Oehler, Quadros parisienses: estética antiburguesa em Baudelaire, Daumier e Heine, Trad. José Marcos Macedo / Samuel Titan Jr., São Paulo, Companhia das Letras, 1997, pp. 4748.

${ }^{66}$ Idem, p. 15.
} 
poesia moderna: nesse sentido, a própria postura clássica do poeta nos anos 50 é um outro aspecto da provocação.

Talvez se possa dizer que a forma clássica provoca o leitor porque este vê naquela o melhor exemplo de uma alienação que, afinal de contas, é a sua própria. Melhor dizendo: em nível superficial, o leitor tem a sensação de que a essa forma não diz respeito ao seu mundo, à sua época, aos seus valores, aos seus interesses, aos seus sentimentos, etc. Sem a transitividade (de forma ou conteúdo), o poema aparece aos olhos do leitor como um bicho exótico e estranho, enigmático e petrificado, que não diz respeito a nada que faça parte do seu cotidiano. A sensação é de que a forma clássica é quase aristocrática: o poeta fala a partir de um outro mundo, outra época, outra posição.

Por outro lado, o leitor que procura desvendar o porquê do poema, percebe que a própria posição aristocrática do eu lírico não se sustenta em si mesma: essa posição assumida pelo eu lírico, que poderia conservar a sua integridade em relação às aporias e os impasses da sociedade moderna, é só uma máscara frágil que não consegue ocultar o fato de que o sistema de violências mútuas que o poeta estabelece com o leitor traz o risco da perda da subjetividade lírica na sociedade moderna.

O eu lírico não está confinado na sua torre de marfim, está preso ao chão dos acontecimentos: o que Drummond faz é transportar para uma suposta distância histórica uma distância que é atual; o poema torna aparentemente clássico uma aporia e um impasse moderno. A forma clássica aparece, pois, como um recurso para aumentar o efeito e a percepção da alienação do homem na sociedade moderna. 
Do exposto até aqui, percebemos que a violência está presente nos mais variados níveis de "Oficina irritada": no conteúdo da mensagem; na aliteração das oclusivas; na criação de imagens noturnas e provocativas; na exclusão do leitor do processo artístico; no choque com o mercado cultural, na medida em que não o poeta quer oferecer o prazer, e sim a agressão ao consumidor; no uso da forma clássica no período em que as formas modernistas eram parte do cânone estabelecido.

Não me parece um exagero assinalar que o poema se caracteriza por ser a representação da generalização da violência na sociedade contemporânea: Claro enigma foi escrito poucos anos após a II Guerra Mundial, que, como se sabe, foi um dos auges da banalização da violência: o desenvolvimento da indústria bélica levou os conflitos a um outro patamar (a criação de armas de destruição em massa, por exemplo); as trincheiras já não eram mais os limites que serviam de proteção aos países; em diversas ocasiões, os civis sentiram foram vítimas dos horrores da devastação da guerra - em termos físicos, psicológicos, morais, etc. Creio que a banalização da violência está representada, inclusive, na aceitação da noite, que, pegando o vínculo de Betina Bischof,

parece articular um vínculo com um sentimento do mundo, revelando os "tons de sombra" (como diz o próprio Drummond num poema dedicado "A Goeldi") de que se compõe a realidade. Nesse sentido, o escurecimento do verso ecoa um mundo também escurecido e, no esforço de trazê-lo à tona, desenha igualmente uma poética, amalgamando a dificuldade ao perfil mais nítido - no delinear dos "tons de sombra" ali traçados - do mundo e do sujeito, em Claro enigma ${ }^{67}$.

\footnotetext{
${ }^{67}$ Betina Bischof, Op. cit., pp. 11-12.
} 
Sob esse ponto de vista, "Oficina irritada" é um mergulho profundo na experiência da modernidade: o poeta incorpora e representa a generalização e banalização da violência. Na análise que fez da obra de Baudelaire, Dolf Oehler chegou a comentar de que maneira o poeta francês representou esse tema na sua obra:

a cumplicidade com tal literatura não é puramente um prazer; infiltrar-se nela pressupõe deixarse infiltrar por ela. E isso não apenas no sentido geral da hermenêutica: Chambres fala de uma "violência simbólica" como uma "resposta à violência repressiva" presente em Au lecteur [...] é a violência exercida por um espírito de perversidade que atua tanto no indivíduo quanto na sociedade, violência que ameaça destruir o desejo de saber, a razão, o propósito da salvação moral do Renascimento e do lluminismo, e que consagra a humanidade ao declínio. Se para o lluminismo e para Hegel o tédio era ainda um motor de progresso [...]. após os massacres de junho [...]. o tédio aparece como o principal agente da destruição da verdade e da vida. Esse tédio, alegoria da época, é também a encarnação do leitor hipócrita que em seus devaneios abandona-se a todos os horrores de que sua memória não quer mais saber. Baudelaire denuncia no leitor não só o que Benjamin chama de "o menos aprovador", mas também o indivíduo o mais incapaz, e devido mesmo a essa incapacidade, capaz do pior. A banalidade de seu cotidiano não é outra senão a continuidade, não totalmente inconsciente, mas absolutamente negada, dos processos sangrentos do passado e a preparação para a brutalidade dos que virão. Essa resposta endereçada ao leitor é, assim, uma impiedosa análise da sociedade burguesa pós-junho [de 1848], que descobre ao mesmo tempo a banalidade do mal $[\ldots]$ e a verossimilhança fundamental que se repetem das catástrofes como as que acabam de atravessar: Au lecteur, não fazendo diferença entre o crime real e o fantasiado, permitiu falar de catástrofe permanente, o que é para Baudelaire a modernidade: um longo redemoinho da humanidade sobre ela mesma num círculo infernal antes que, cedo ou tarde, ela acabasse no inferno. Mais ainda que a epígrafe de d'Aubigné à qual ele se vincula, esse poema diz ao leitor como ler o volume poético e o contexto histórico-social onde brotaram essas 'flores' de Baudelaire. Esta indicação de leitura conservou sua atualidade não só até a Comuna, mas 
também após duas guerras mundiais, após Auschwitz e Hiroshima ${ }^{68}$.

De forma modificada, mas com o mesmo ímpeto de antes, Drummond repete em "Oficina irritada" a violência de "A flor e a náusea" para tirar o leitor do estado de tédio em que se encontra:

Pôr fogo em tudo, inclusive em mim.

Ao menino de 1918 chamavam de anarquista.

Porém meu ódio é o melhor de mim.

Com ele me salvo

e dou a poucos uma esperança mínima.

Não fosse a violência, que enche o poema de dissonâncias, este seria apenas a reprodução da alienação. É por meio da provocação que Drummond reverte o quadro comum das relações sociais, de onde é possível (uma vez que a violência atinja deveras a sensibilidade do leitor) a crítica ao modo de vida na sociedade moderna.

A provocação rompe as regras sociais de etiqueta e conduta; o leitor é tirado do seu círculo de conforto e (se quer entender a obra) obrigado a reproduzir passo a passo a construção da obra para entender o porquê da provocação, que chega aos seus limites na própria exclusão do público como parte integrante do sistema literário convencional; e que, por sua vez, toca na própria possibilidade da subjetividade do eu lírico. A grandeza de "Oficina irritada" está, creio, em fazer da violência um sistema poético coerente que imita a violência da sociedade e, ao mesmo tempo, surge como um meio de

${ }^{68}$ Dolf Oehler apud Vagner Camilo, Op. cit., p. 201-202. 
criticá-la. 


\section{Leitura de "F"}

By this art you may contemplate the variation of the 23 letters...

The anatomy of melancholy

Para dizer o óbvio, a palavra-chave de "F" é "forma": a sua ligação com o título é clara (f é a sua letra inicial), e sugestiva (o título é a abreviatura do indizível da "forma"). O jogo da letra e da palavra já acusa o intervalo entre o sujeito e o objeto:

forma
forma
forma

que se esquiva

por isso mesmo viva

no morto que a procura

a cor não pousa

nem a densidade habita

nessa que antes de ser

já

deixou de ser não será

mas é

forma

festa

fonte 
flama

filme

e não encontrar-te é nenhum desgosto

pois abarrotas o largo armazém do factível

onde a realidade é maior do que a realidade

$\mathrm{Na}$ abertura do poema, a palavra "forma" é curiosamente repetida três vezes em três versos:

\author{
forma \\ forma \\ forma
}

A sensação é de que o tom dos versos se confunde com uma nomeação impessoal; aqui a repetição traz alguns problemas, pois emperra as engrenagens do poema ao apontar incessantemente para si mesma (nas imagens criadas pela leitura, não é difícil imaginar uma lista interminável com a palavra "forma"). A pergunta é natural: onde está a voz lírica? Mas uma segunda sensação é de que o tom dos versos (que podem ser um falso vocativo) também se confunde com uma invocação do sujeito - a palavra "forma" se impõe de uma maneira tão obsessiva que me faz lembrar estrutura repetitiva das fórmulas religiosas usadas para adorar, aplacar, invocar ou exorcizar os espíritos. Em resumo: a invocação do sujeito irrompe, ainda que timidamente, da nomeação impessoal. Na seqüência do poema,

forma

que se esquiva, 
fica claro o intervalo entre o sujeito e o objeto, o que confirma o tom tanto da nomeação impessoal (isto é, da "forma" que não traz a voz lírica) quanto da invocação do sujeito, que insiste em invocar a presença do objeto do desejo. $\mathrm{O}$ verso 5 , por sua vez,

por isso mesmo viva

está em posição estratégica: pela rima (esquiva / viva), o verso reitera e amplia o universo de sentido da palavra "forma" - é da sua natureza não se entregar ao sujeito poético; pelo contraste, o verso já aponta sutilmente para a entrada da voz lírica, que aparece no verso 6 sob a figura do "morto":

no morto que a procura

A rede de imagens provoca um certo mal estar: apontar justamente para o "morto" é sublinhar a inutilidade da sua "procura" - quem canta já não tem mais voz lírica. De início, havia a ausência do objeto esquivo; agora, há a ausência do eu lírico. Em outros termos, a lírica pede o espraiar da substância objectual na vida anímica: se, por um lado, o poeta não dá conta de achar a "forma", interioriza, por outro, a ausência do encontro, e faz com que o tom do sujeito ("morto") seja condizente com o tom do objeto ("forma"). A peculiaridade desse exótico "vínculo" pode ser vista na estrofe:

a cor não pousa

nem a densidade habita

nessa que antes de ser 
já

deixou de ser não será

mas é

Os versos se referem à palavra "forma", mas são construídos em torno da associação com a palavra "morto". O verso "a cor não pousa" traz o sabor inconfundível dos ditos populares como "estar sem cor", "ficar sem cor": a área de influência da palavra "morto" se estende ao conteúdo da estrofe - é a marca de uma ausência. Daí o poema ser atingido subitamente por uma série de explosões isoladas (vv. 10-12): aliada aos paradoxos desses versos, a falta de pontuação aponta para a quebra da seqüência lógica do tempo da escrita, traduzindo a ausência do sujeito; por sua vez, a disposição espacial dos versos dá a sensação dissipação, traduzindo a ausência do objeto - o que afeta a curiosa lista de palavras que surge no poema, em que a palavra "forma" não é mais repetida, e sim desdobrada em diversas outras palavras que a figura do "morto" colhe ao acaso como se fosse uma "enumeração caótica":

$$
\begin{aligned}
& \text { forma } \\
& \text { festa } \\
& \text { fonte } \\
& \text { flama } \\
& \text { filme }
\end{aligned}
$$

É no ensaio de Leo Spitzer que está o conceito de "enumeração caótica", que 
gigantesco y lo minúsculo, la naturaleza y los productos de la civilización humana, como un niño que estuviera hojeando el catálogo de una gran tienda y anotando en desorden los artículos que el azar pusiera bajo tu vista; pero un ninõ además sabio y poeta, extrajera poesía y pensamiento de una lista de áridas palabras; un niño genial, con el gênio verbal de un Victor Hugo $^{69}$.

No caso de Walt Whitman, por exemplo, um dos objetos de estudo de Leo Spitzer, a enumeração caótica tem como base o panteísmo: as "cosas más díspares" estão conectadas por uma unidade que governa o mundo. No caso da obra drummondiana, o sentido da enumeração caótica é, ao contrário, dar a ver a fragmentação da experiência na modernidade: a "festa", a "fonte", a "flama" e o "filme" são espécies de desdobramentos fragmentados da unidade que a "forma" contém, mas que é esquiva ao sujeito.

Até este ponto de "F", não há por onde negar que o poema sofreu uma influência da estética construtiva: na disposição espacial dos versos, na obsessão com o caráter objectual da palavra, no jogo com as estruturas da composição, na atomização vocabular, na sintaxe reduzida (praticamente fragmentada), no uso de elementos mínimos de conexão entre as partes, na quase ausência da voz lírica.

Nos versos finais, no entanto, há uma quebra na lógica do poema, pois o poeta tenta recuperar a voz subjetiva:

e não encontrar-te é nenhum desgosto
pois abarrotas o largo armazém do factível
onde a realidade é maior do que a realidade

${ }^{69}$ Leo Spitzer, "La enumeración caótica en la poesía moderna”, Lingüística y história literária, Madrid, Gredos, 1961. 
A diferença de forma e conteúdo entre os versos 18-20 e os anteriores é brutal: o poema traz claramente a voz do poeta; os versos adquirem um contorno mais clássico, deixando de lado a experimentação lingüística que vinha sendo a tônica principal da expressão; os elementos de coesão e coerência aparecem para encadear o discurso e acusar a presença de um sujeito que o organiza.

Tudo isso porque a "forma" não é mais desejável, agora que, retomando a lista de palavras anteriormente expressas, foi convertida em "factível". A ausência de desgosto parece estar relacionada ao fato de que a "forma factível" é a representação da consciência da impossibilidade da "forma", o que atua como uma espécie de consolo que assegura o papel decisivo do eu lírico na composição poética.

Para entender a mescla estilística (entre a técnica concreta e, por assim dizer, o verso tradicional) é preciso ver de perto ao menos três coordenadas que estão, creio, na base do poema: a subjetividade da voz lírica, uma estética com um quê de construtivista e o processo histórico que estava em andamento no país.

É bom lembrar que Lição de coisas foi escrito mais ou menos no final dos anos 50 e no início dos anos 60: época do projeto desenvolvimentista do governo JK, que visava ao progresso da nação através do desenvolvimento industrial, tecnológico e científico. Conectado ao espírito de época, o movimento concretista trazia para o campo da estética as mais recentes inovações dos campos do saber, a fim de fazer a atualização da literatura brasileira de acordo com a nova ordem. Para ver certos pontos da relação entre o concretismo e o período referido, transcrevo as idéias de lumna Maria 


\section{Simom, que apontou com agudeza que}

a atualização concretista dos anos 50 criou uma idéia de vanguarda diretamente vinculada à mitologia da nova era industrial e tecnológica do pós-guerra, com suas invenções científicas, planejamento racional, novos meios de informação e comunicação. Nesse momento, relembremos, o nacional-desenvolvimentismo (1956-60) alimentava a esperança de rápida saída do subdesenvolvimento por meio da industrialização, da ampliação do mercado interno, da substituição das importações, da economia planejada. O novo então preconizado pelo concretismo implicava uma adesão irrestrita a esses fatores, fantasiando um processo de superação do subdesenvolvimento com racionalidade poética e invenção criativa. Ao contrário dos modernistas, que pretendiam que os traços brasileiros aflorassem ao máximo à medida que 0 progresso urbano-industrial se instaurasse, neste outro momento, superar 0 subdesenvolvimento queria dizer literalmente superar os traços nacionais em prol de uma modernidade pensada em abstrato, independentemente dos processos sociais, econômicos, técnicos, urbanos que estavam de fato em andamento. A confiança cega no progresso forjou uma noção muito peculiar de engajamento político-social, cujas formas de intervenção seriam mais efetivas quanto mais esteticistas fossem [...] Dada a natureza anômala da modernização brasileira, tais projeções imaginárias abstraíam seu "lugar social", para falar como Adorno, criando uma ideologia da forma capaz ela mesma de impulsionar o desenvolvimento do país, já sem qualquer ponta de desconfiança. Em resumo, por desconhecer seu horizonte histórico imediato, o esteticismo dessa vanguarda tanto se apóia em procedimentos técnicos e formais que só Ihe resta idealizar o controle racional dos materiais próprios do poema, como se este já fosse a desejada transformação da sociedade, a um passo da universalidade. Uma tal dessintonia com o sentido histórico e cultural da modernização desigual não poderia deixar de se refletir na própria intervenção concretista, que fora concebida para um mundo de "objetosbens-de-consumo sim, mas no âmbito do pensamento e da sensibilidade, inconversíveis que são a valores meramente utilitários", ou seja, um mundo em que até a mercadoria era idealizada ${ }^{70}$.

\footnotetext{
${ }^{70}$ lumna Maria Simon, "Considerações sobre a poesia brasileira em fim de século", Novos estudos Cebrap, São Paulo, Cebrap, 1999, n. 55, pp. 31-32.
} 
A partir das idéias acima, é possível dizer que o concretismo tinha uma ideologia da forma que vendia como desenvolvimento, passando a largo das aporias da realidade brasileira de então; a abstração geométrica dos concretistas está presente na fórmula: "o poema concreto ou ideograma passa a ser um campo relacional de funções" ${ }^{\prime 71}$. Por sua vez, o governo JK - talvez mais atrelado ao contexto histórico do que o concretismo - não deixava de fazer uma certa idealização do nacional-desenvolvimentismo: o lema "cinqüenta anos em cinco" é sintomático ou de uma euforia demasiada ou de uma opção por fazer vistas grossas aos problemas do país.

A partir dos dados apontados, é preciso fazer um breve retrospecto da modernização na sociedade brasileira para ver a sua relação com a subjetividade drummondiana. Já em 1930, o poema "Sinal de apito" alertava sobre os riscos do modus operandi da metrópole, que mecanizava as relações sociais. De acordo com Mário de Andrade a existência na sociedade ficava "reduzida a um simples maquinismo de gestos e sinais""

\footnotetext{
Um silvo breve. Atenção, siga.

Dois silvos breves: Pare.

Um silvo breve à noite: Acenda a lanterna.

Um silvo longo: Diminua a marcha.

Um silvo longo e breve: Motoristas a postos.
}

(A este sinal todos os motoristas tomam lugar nos seus veículos para movimentá-los imediatamente).

\footnotetext{
71 Décio Pignatari, Teoria da poesia concreta, São Paulo, Ateliê Editorial, 2006.

$72 \quad$ Mário de Andrade, Op. cit., p. 71.
} 
Trinta anos depois de "Sinal de apito", a pressão do contexto histórico sobre a subjetividade atuava mais veementemente. Perry Anderson chegou a comentar que

a burguesia - em sentido estrito, como classe dotada de autoconsciência e moral - estava quase extinta. Aqui e ali, bolsões de um cenário burguês tradicional ainda podem ser encontrados em cidades de província na Europa e talvez em certas regiões da América do Norte tipicamente preservadas pela fé religiosa: redes familiares no Vêneto ou em terras bascas, notáveis conservadores no Bordelais, certos setores de classe média na Alemanha e assim por diante. Mas, em geral, a burguesia tal como Baudelaire ou Marx, Ibsen ou Rimbaud, Grosz ou Brecht - ou mesmo Sartre e O'Hara - conheceram, é coisa do passado. No lugar desse sólido anfiteatro, há um aquário de formas flutuantes e evanescentes - os projetistas e gerentes, auditores e zeladores, administradores e especuladores do capital contemporâneo: funções de um universo monetário que não conhece rigidez ou identidades fixas ${ }^{73}$.

A partir dos aspectos apontados parece ser possível estabelecer algumas interpretações ao poema "F". No momento em que se apropria da técnica concreta e, portanto, do contexto histórico que está na sua base, o poeta subjetivou (ainda que ligeiramente) essa técnica (por exemplo, a invocação do sujeito por trás da nomeação impessoal) para problematizar o tema da perda do teor subjetivo na experiência da modernidade. Em outros termos, sem idealização ou abstração, a estética com um quê de construtivista do poema traz o fato de que o tom impessoal ("morto" / "forma") é resultado do fim da voz lírica por causa das implicações do processo histórico que vinha se formando no país desde o início do século - de que a luta dos poetas concretos "contra a poesia de expressão subjetiva" é uma das faces, no plano

\footnotetext{
${ }^{73}$ Perry Anderson, As origens da pós-modernidade, São Paulo, Jorge Zahar, 1999.
} 
artístico. lumna Maria Simon chegou a dizer em um curso que Drummond foi o último grande representante do individualismo burguês. Por sua vez, o próprio poeta tratou de expor a consciência da sua individualidade quando disse em "Desfile" que

Se eu morrer, morre comigo

um certo modo de ver.

Para uma obra sempre preocupada com a subjetividade como a de Drummond, abrir mão dela nesse poema significa um notável compromisso estético e político em não recalcar as aporias e os impasses do material artístico e histórico.

Daí que o terceto final soe como deslocado e anacrônico em relação ao conjunto: o poema está usando os procedimentos experimentais da estética construtivista para expressar o cenário nacional-desenvolvimentista - mas não com o intuito de projetar uma sociedade moderna já realizada no campo estético. A tentativa de preservar a subjetividade em um cenário que incentiva a racionalidade impessoal do progresso industrial e tecnológico só pode parecer coisa do passado, que o poeta projeta no estilo algo clássico dos versos finais.

Nesse sentido, o caráter anacrônico desses versos não se caracteriza por ser um defeito, uma vez que Drummond conseguiu inserir essa caráter (que poderia ser uma fraqueza) na estrutura mais geral do poema para criar uma tensão. Curiosamente, o problema de "F" é oposto ao de "Morte do leiteiro": neste, a solução ideológica surge porque o eu lírico não conseguiu interiorizar a objetividade a ponto de conseguir projetar todas as tensões do 
contexto histórico; naquele, o terceto anacrônico surge porque a consciência lírica, apesar de ter interiorizado a objetividade, viu aí problemas dramáticos que a levaram a querer negar a "forma" e preservar - em alguma medida - a voz lírica central. Se em "F", o eu lírico está no centro da cena, em "Morte do leiteiro" está distanciado. A tensão de "F" é maior, é mais instigante para o pensamento crítico do que "Morte do leiteiro" justamente pelo fato da subjetividade estar mais implicada: desde 1920 até aqui, vimos que as aporias e os impasses existem na sociedade, mas só adquirem um tratamento realmente convincente quando passam pelo espírito subjetivo, já que, em si mesmos, são matéria sem sabor; é através do eu lírico que se divisa o contexto histórico, político e social na obra de Drummond. 


\section{Bibliografia}

Andrade, Carlos Drummond de. Confissões de Minas. Rio de Janeiro, Americ Edit, 1944.

. Passeios na ilha: divagações sobre a vida literária e outras matérias.

Rio de Janeiro, Simões, 1952.

. Reunião: 10 livros de poesia. Int. Antônio Houaiss. Rio de Janeiro, José Olympio, 1980.

(Org.). A lição do amigo: cartas de Mário de Andrade a Carlos

Drummond de Andrade. Rio de Janeiro, Record, 1988.

. Antologia poética. Rio de Janeiro, Record, 1997.

. Poesia completa. Rio de Janeiro, Nova Aguilar, 2002.

. Prosa seleta. Rio de Janeiro, Nova Aguilar, 2003.

ACHCAR, Francisco. A rosa do povo e Claro enigma: roteiro de leitura. São Paulo, Ática, 1993.

ANDRADE, Mário de. "A poesia em 1930". Aspectos da literatura brasileira. São 
Paulo, Martins, 1974.

ARRIGUCCI Jr., Davi. Coração partido: uma análise da poesia reflexiva de Drummond. São Paulo, Cosac Naify, 2002.

BANDEIRA, Manuel. "Carlos Drummond de Andrade". Seleta de prosa, Rio de Janeiro, Nova Fronteira, 1997.

Barbosa, Rita de Cássia. Poemas eróticos de Carlos Drummond de Andrade. São Paulo, Ática, 1987.

BISCHOF, Betina. Razão da recusa: um estudo da poesia de Carlos Drummond de Andrade. São Paulo, Nankin, 2005.

BosI, Alfredo. "Carlos Drummond de Andrade". Histórica concisa da literatura brasileira. São Paulo, Cultrix, 1994.

. "A máquina do mundo: entre o ser e a alegoria". Céu, inferno: ensaios de crítica literária e ideológica. São Paulo, Duas Cidades / Ed. 34, 2003.

Brayner, Sônia (Org.). Carlos Drummond de Andrade. Rio de Janeiro, Civilização Brasileira, 1978.

CANÇADO, José Maria. Os sapatos de Orfeu. São Paulo, Scritta, 1993.

CANDIDO, Antonio. "Poesia e ficção na autobiografia". A educação pela noite e outros ensaios. São Paulo, Ática, 1985.

. "Drummond prosador". Recortes. São Paulo, Companhia das Letras, 1993. . "Inquietudes na poesia de Drummond". Vários escritos. São Paulo, Duas Cidades, 1995.

CAmILO, Vagner. Drummond: da rosa do povo à rosa das trevas. São Paulo, Ateliê Editorial, 2001. 
CôELHO, Joaquim Francisco. Terra e família na poesia de Carlos Drummond de Andrade. Belém, Universidade Federal do Pará, 1975.

DAmAZıO, Reynaldo (Org.). Drummond revisitado. São Paulo, Universidade São Marcos, 2002.

ESCOLASTICO, Cristiane. "Um guardião desarmado, o reconhecimento do trágico". Magma. São Paulo, Humanitas, 1997, n. 4.

GARCIA, Othon M. Esfinge clara: palavra-puxa-palavra em Carlos Drummond de Andrade. Rio de Janeiro, Livraria São José, 1955.

GLedson, John. Poesia e poética em Carlos Drummond de Andrade. São Paulo, Duas Cidades, 1981.

HouAISS, Antonio. Drummond mais seis poetas e um problema. Rio de Janeiro, Imago, 1976.

LAFETÁ, João Luiz. "Leitura de Campo de flores". Revista do Instituto de Estudos Brasileiros. São Paulo, leb, 1972, n. 11.

LIMA, Luiz Costa. "O princípio-corrosão na poesia de Carlos Drummond de Andrade". Lira e antilira: Mário, Drummond e Cabral. Rio de Janeiro, Topbooks, 1995.

LIMA, Mirella Márcia Longo Vieira. Confidência mineira: o amor na poesia de Carlos Drummond de Andrade. São Paulo, Edusp, 1995.

MaRTins, Hélcio. A rima na poesia de Carlos Drummond de Andrade. Rio de Janeiro, José Olympio, 1968.

MERQUIOR, José Guilherme. Verso universo em Drummond. Rio de Janeiro, José Olympio, 1976.

NETO, Geneton Moraes. O dossiê Drummond. São Paulo, Globo, 1994.

PIGNATARI, Décio. "Áporo”. Contracomunicação. São Paulo, Ateliê Editorial, 2004. 
SantANNA, Afonso Romano de. Drummond: o gauche no tempo. Rio de Janeiro, Record, 1992.

SIMON, lumna Maria. A rosa do povo: uma poética do risco. Assis, Faculdade de Filosofia, Letras e Ciências de Assis, 1973.

TELLES, Gilberto Mendonça. Drummond: a estilística da repetição. Rio de Janeiro, José Olympio, 1970.

VILlAÇA, Alcides Celso de Oliveira. Consciência lírica em Drummond. São Paulo, Universidade de São Paulo, 1976, . "Capítulo drummondiano". Lendo poetas brasileiros. São Paulo, Universidade de São Paulo, 2002. . Passos de Drummond. São Paulo, Cosac Naify, 2006.

AdORNO, Theodor. "Aquellos años veinte". Intervenciones. Caracas, Monte Ávila, 1969.

. Notas de literatura I. Trad. Jorge de Almeida. São Paulo, Duas Cidades / Ed. 34, 2003. . Teoria estética. Trad. Artur Morão. Lisboa, Edições 70, 2006.

ANDERSON, Perry. "Modernidade e revolução". Novos estudos Cebrap, São Paulo, Cebrap, 1986, n. 14. . As origens da pós-modernidade. Trad. Marcus Penchel. São Paulo, Jorge Zahar, 1999. 
AndRAde, Oswald de. Poesias reunidas. São Paulo, Círculo do Livro, 1976.

AUERBACH, Erich. "As flores do mal e o sublime". Ensaios de literatura ocidental. Trad. José Marcos Macedo / Samuel Titan Jr. São Paulo, Duas Cidades / Ed. 34, 2007.

BAUDELAIRE, Charles. As flores do mal. Trad. Ivan Junqueira. Rio de Janeiro, Nova Fronteira, 1985.

. Pequenos poemas em prosa. Trad. Dorothée de Bruchard. São Paulo, Hedras, 2007.

Benjamin, Walter. Charles Baudelaire: um lírico no auge do capitalismo. Trad.

Hemerson Alves Baptista / José Martins Barbosa. São Paulo, Brasiliense, 1989.

. Textos escolhidos. Trad. José Lino Grünnewald et al. São Paulo, Abril, 1975.

BENVESNISTE, Emile. "Da subjetividade na linguagem". Problemas de lingüística geral. Campinas, Pontes, 1991.

BERGSON, Henri. O riso: ensaio sobre a significação da comicidade. Trad. Ivone Castilho Benedetti. São Paulo, Martins Fontes, 2001.

BosI, Alfredo. "Sobre alguns modos de ler poesia: memórias e reflexões". Leitura de poesia. São Paulo, Ática, 1996. . O ser e o tempo da poesia. São Paulo, Cultrix, 1997.

BRITO, Ronaldo. Experiência crítica. Org. Sueli de Lima. São Paulo, Cosac Naify, 2005.

BÜRGER, Peter. "O declínio da era moderna". Novos estudos Cebrap. São Paulo, Cebrap, 1988, n. 20. .Teoria da vanguarda. Trad. Ernesto Sampaio. Lisboa, Vega / 
Universidade, 1993.

CAMPOS, Augusto de. Teoria da poesia concreta. São Paulo, Ateliê Editorial, 2006.

CANDIDO, Antonio. Na sala de aula: caderno de análise literária. São Paulo, Ática, 1986.

FRIEDRICH, Hugo. Estrutura da lírica moderna. São Paulo, Duas Cidades, 1978. HEGEL, Georg. "A poesia". Curso de estética: o sistema das artes. Trad. Álvaro Ribeiro, São Paulo, Martins Fontes, 1997.

JAMESON, "Pós-modernidade e sociedade de consumo". Novos estudos Cebrap. São Paulo, Cebrap, 1985, n. 12.

LUKÁCS, Georg. A teoria do romance. Trad. José Marcos Macedo. São Paulo, Duas Cidades / Ed. 34, 2000.

MARTINS, Luiz Renato. Manet: uma mulher de negócios, um almoço no parque e um bar. Rio de Janeiro, Jorge Zahar, 2007.

NAVES, Rodrigo. A forma difícil: ensaios sobre a arte brasileira. São Paulo, Ática, 1997.

OEHLER, Dolf. Quadros parisienses: estética anti-burguesa em Baudelaire, Daumier e Heine. Trad. José Marcos Macedo / Samuel Titan Jr. São Paulo, Companhia das Letras, 1997.

PAES, José Paulo. "O pobre diabo no romance brasileiro". Novos estudos Cebrap. São Paulo, 1988, n. 20.

PAZ, Octavio. A outra voz. Trad Wladir Dupont. São Paulo, Siciliano, 1993. . Signos em rotação. Trad. Sebastião Uchoa Leite. São Paulo, Perspectiva, 1996. . El arco y la lira. México, Fondo de Cultura Económica, 2003. 
. Os filhos do barro: do romantismo às vanguardas. Trad. Olga Savary.

São Paulo, Nova Fronteira, 1984.

RAYMOND, Marcel. De Baudelaire ao surrealismo. Trad. Fúlvia M. L. Moretto /

Guacira Marcondes Machado. São Paulo, Edusp, 1997.

Rosenfeld, Anatol. O teatro épico. São Paulo, Perspectiva, 2008.

SCHWARZ, Roberto. Que horas são? São Paulo, Companhia das Letras, 1987. . "O país do elefante". Caderno Mais! São Paulo, Folha de São Paulo,

$10 / 03 / 2002$.

SPITZER, Leo. "La enumeración caótica em la poesia moderna". Lingüística y história literária. Madrid, Editora Gredos, 1961.

. Três poemas sobre o êxtase. Trad. Samuel Titan Jr. São Paulo, Cosac Naify, 2003.

SIMON, lumna Maria. "Considerações sobre a poesia brasileira em fim de século". Novos estudos Cebrap. São Paulo, Cebrap, 1999, n. 55.

SzondI, Peter. Teoria do drama moderno. Trad. Luiz Sérgio Rêpa. São Paulo, Cosac Naify, 2001.

VALÉRY, Paul. "Situação de Baudelaire". Variedades. Trad. Maiza Martins Siqueira. São Paulo, lluminuras, 2007. 